Article

\title{
Seismic-Geological Integrated Study on Sedimentary Evolution and Peat Accumulation Regularity of the Shanxi Formation in Xinjing Mining Area, Qinshui Basin
}

\author{
Bo Liu ${ }^{1,2}$, Suoliang Chang ${ }^{1,2}$, Sheng Zhang ${ }^{1,2,3, * \mathbb{D}}$, Yanrong Li $^{1}$, Zhihua Yang ${ }^{4}$, Zuiliang Liu ${ }^{4}$ \\ and Qiang Chen ${ }^{1,2}$ (D)
}

check for updates

Citation: Liu, B.; Chang, S.; Zhang, S.; Li, Y.; Yang, Z.; Liu, Z.; Chen, Q. Seismic-Geological Integrated Study on Sedimentary Evolution and Peat Accumulation Regularity of the Shanxi Formation in Xinjing Mining Area, Qinshui Basin. Energies 2022, 15, 1851. https://doi.org/10.3390/ en15051851

Academic Editor:

Nikolaos Koukouzas

Received: 31 January 2022

Accepted: 28 February 2022

Published: 2 March 2022

Publisher's Note: MDPI stays neutral with regard to jurisdictional claims in published maps and institutional affiliations.

Copyright: (C) 2022 by the authors. Licensee MDPI, Basel, Switzerland. This article is an open access article distributed under the terms and conditions of the Creative Commons Attribution (CC BY) license (https:// creativecommons.org/licenses/by/ $4.0 /)$.
1 Department of Earth Science and Engineering, Taiyuan University of Technology, Taiyuan 030024, China; liu_deeper@163.com (B.L.); changsuoliang@tyut.edu.cn (S.C.); li.dennis@hotmail.com (Y.L.); chenqiang@tyut.edu.cn (Q.C.)

2 Shanxi Key Laboratory of Coal \& Coal-Measure Gas Geology, Taiyuan 030024, China

3 Shanxi Institute of Geological Survey, Taiyuan 030006, China

4 Department of Geology and Survey, Huayang New Material Technology Group Co., Ltd., Yangquan 045000, China; ymdc2009@163.com (Z.Y.); liuzuiliang@163.com (Z.L.)

* Correspondence: zhangsheng@tyut.edu.cn

\begin{abstract}
Accurate identification of the lithofacies and sedimentary facies of coal-bearing series is significant in the study of peat accumulation, coal thickness variation and coal-measured unconventional gas. This research integrated core, logging and 3D seismic data to conduct a comprehensive seismicgeological study on the sedimentary evolution characteristics and peat accumulation regularity of the Shanxi Formation in the Xinjing mining area of the Qinshui Basin. Firstly, the high-resolution sequence interface was identified, and the isochronous stratigraphic framework of the coal-bearing series was constructed. Then, the temporal and spatial evolution of sedimentary filling and sedimentary facies was dynamically analyzed using waveform clustering, phase rotation, stratal slice and frequency-division amplitude fusion methods. The results show that the Shanxi Formation in the study area can be divided into one third-order sequence and two fourth-order sequences. It developed a river-dominated deltaic system, mainly with delta plain deposits, and underwent a constructive-abandoned-constructive development stage. The locally distributed No. 6 coal seam was formed in a backswamp environment with distribution constrained by the distributary channels. The delta was abandoned at the later stage of the SS1 sequence, and the peat accumulation rate was balanced with the growth rate of the accommodation, forming a large-area distributed No. 3 thick coal seam. During the formation of the SS2 sequence, the No. 3 coal seam was locally thinned by epigenetic erosion of the river, and the thin coal belt caused by erosion is controlled by the location of the distributary channels and their extension direction. This study can provide a reference for the research on the distribution of thin sand bodies, sedimentary evolution and peat accumulation regularity in the coal-bearing series under the marine-continental transitional environment.
\end{abstract}

Keywords: seismic sedimentology; sedimentary facies evolution; peat accumulation regularity; frequency-division amplitude fusion; thin sand bodies

\section{Introduction}

The study of sedimentary facies is important for the in-depth understanding of the peat-forming environment, peat accumulation regularity and unconventional gas in coal measures during the formation and evolution of a coal-bearing basin [1-6]. Previous studies have shown that the Carboniferous-Permian coal-bearing series in the Yangquan mining area of the Qinshui Basin was formed in the marine-continental transitional environment, and the main coal-bearing strata, the Taiyuan Formation and Shanxi Formation, underwent sedimentary evolution from barrier coast systems to deltaic systems [7-9]. Generally, the 
distribution characteristics of sand bodies and sedimentary facies near coal seams usually have significant effects on peat accumulation, coal thickness variation, coalbed methane enrichment and resource recoverability [8,10-12]. Therefore, it is significant to carry out fine characterization of the sedimentary facies of coal-bearing series under small-scale conditions and their controlling effect on coal seams.

Traditionally, the sequence classification, lithology and sedimentary facies distribution characteristics of coal-bearing strata can be studied based on field outcrops, well logging curves and core data $[2,13]$. However, there is a problem of low resolution in identifying the lateral changes in sedimentary bodies due to the limitations of the research data. Meanwhile, seismic data have the characteristics of dense spatial sampling, which can effectively make up for this deficiency. The study of a stratigraphic sequence and sedimentary system using seismic techniques can be traced back to the seismic stratigraphy proposed by Vail et al., in the 1970s [14]. The internal structure and external morphology of seismic reflections are studied mainly based on the seismic facies, and the temporal and spatial distribution of sedimentary systems is restored through the identification and combination of seismic facies [15-17]. Seismic stratigraphy is more suitable for basin analysis, thick layer sequence classification and early- to middle-term resource exploration and evaluation, but the control accuracy of small-scale sedimentary units and thin sand bodies is still insufficient because of the limitation of seismic resolution.

With the deepening of resource exploration and development, researchers have higher requirements for the accuracy of seismic data interpretation in small-scale geological bodies. Within this context, benefiting from the advancement of 3D seismic technology and the improvement of the quality of seismic data, a new discipline-seismic sedimentologywas developed $[18,19]$. Seismic sedimentology is based on the disciplines of geophysics, seismic stratigraphy and sequence stratigraphy, and the technical means mainly include $90^{\circ}$ phase rotation, stratal slice and frequency division calibration $[20,21]$. Seismic sedimentology studies the stratigraphic lithology, sedimentary genesis, basin filling history and sedimentary system through the integrated analysis of seismic lithology and seismic geomorphology $[18,22]$. It has played an important role in delineating thin sand bodies, predicting favorable reservoirs and comprehensively evaluating potential blocks in the hydrocarbon-bearing sedimentary basin [20,23-25]. However, there are few studies on the sedimentary facies of coal-bearing series by seismic sedimentology, and previous studies have made preliminary attempts to investigate the sedimentary seal ability and the gas content of coal seams by means of seismic sedimentology [11,26]. In fact, the lithological distribution of coal-bearing basins in China is complex and thin layers are commonly developed [2,12], which makes the relationship between lithology and wave impedance more complicated. How to use 3D seismic technology, including but not limited to the seismic sedimentology method, to predict the distribution of thin sand bodies and to finely delineate sedimentary facies in coal-bearing series deserves further study.

In view of the characteristics of thin layers development and rapid lithological changes in the coal-bearing series, this study comprehensively utilized core, well logging and high-quality broadband 3D seismic data, and employed the high-resolution sequence stratigraphy and various seismic interpretation methods, such as waveform clustering, stratal slice and frequency-division amplitude fusion, to finely delineate the distribution of sand bodies and sedimentary facies in each sequence of the Shanxi Formation of the Xinjing mining area. Besides, the peat accumulation regularity of the main coal seams and the applicability of seismic sedimentology in the prediction of sedimentary facies in coal-bearing series were discussed.

\section{Geological Background}

\subsection{Tectonic Setting}

Qinshui Basin is a Mesozoic basin between the Taihang Uplift and the Lvliang Uplift, presenting a large-scale NNE strike complex syncline [10]. The research area is located in the northwest of the Yangquan mining area and the northeastern margin of the Qinshui 
Basin. The main body of the stratigraphy is a monoclinic structure with NW strike and SW dipping tendency, and the sublevel NNE-NE oriented spreading of the syncline and anticline are developed alternately in en echelon pattern, and the geological structures are relatively simple (Figure 1).

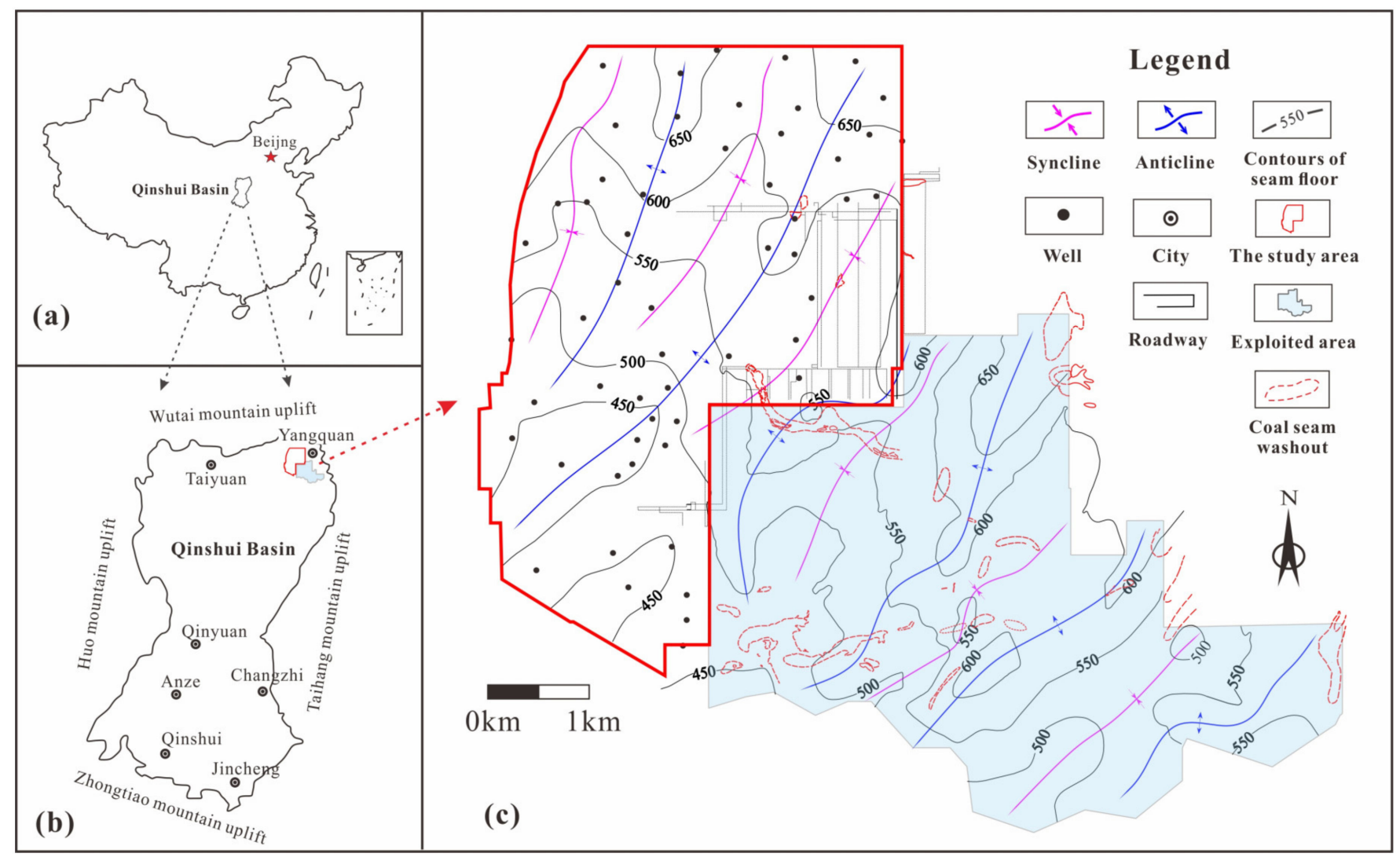

Figure 1. Map of the research area showing the geological structures and wells. (a) Location map of the Qinshui Basin. (b) Location of the research area in Qinshui Basin. (c) The major structures and wells in research area. Notably, the exploited area shows that coal seam was significantly affected by erosion.

\subsection{Coal-Bearing Formations and Coal Seams}

In the research area, the strata preserved include Ordovician, Pennsylvanian, Permian, Triassic to Quaternary units. The main coal-bearing strata are Pennsylvania Taiyuan Formation $\left(\mathrm{C}_{3} \mathrm{t}\right)$ and Permian Shanxi Formation $\left(\mathrm{P}_{1} \mathrm{~s}\right)$. The thickness of the Shanxi Formation ranges from about 45 to $72 \mathrm{~m}$, with an average of $56 \mathrm{~m}$ (Figure 2). The No. 3 coal seam in the Shanxi Formation has a thickness of 0.75 to $4.31 \mathrm{~m}$ (average $2.33 \mathrm{~m}$ ), which is stable and mineable in the whole area, while the No. 6 coal seam is 0 to $3.10 \mathrm{~m}$ thick (average $1.38 \mathrm{~m}$ ), which is unstable and locally recoverable. Other coal seams are unstable thin seams or coal lines. Meanwhile, the exploited region in the southeastern part of the study area shows that the No. 3 coal seam was obviously eroded by the river, and the sandstones on the roof of the coal seam are in scour contact with the No. 3 coal seam (Figure 1). The coal seam was thinned or even completely pinched out in the erosion zone, with coal loss of $10 \%$ to $60 \%$ and ash content increasing by about $2 \%$. This study focuses on the accumulation regularity of the No. 3 and No. 6 coal seams. 


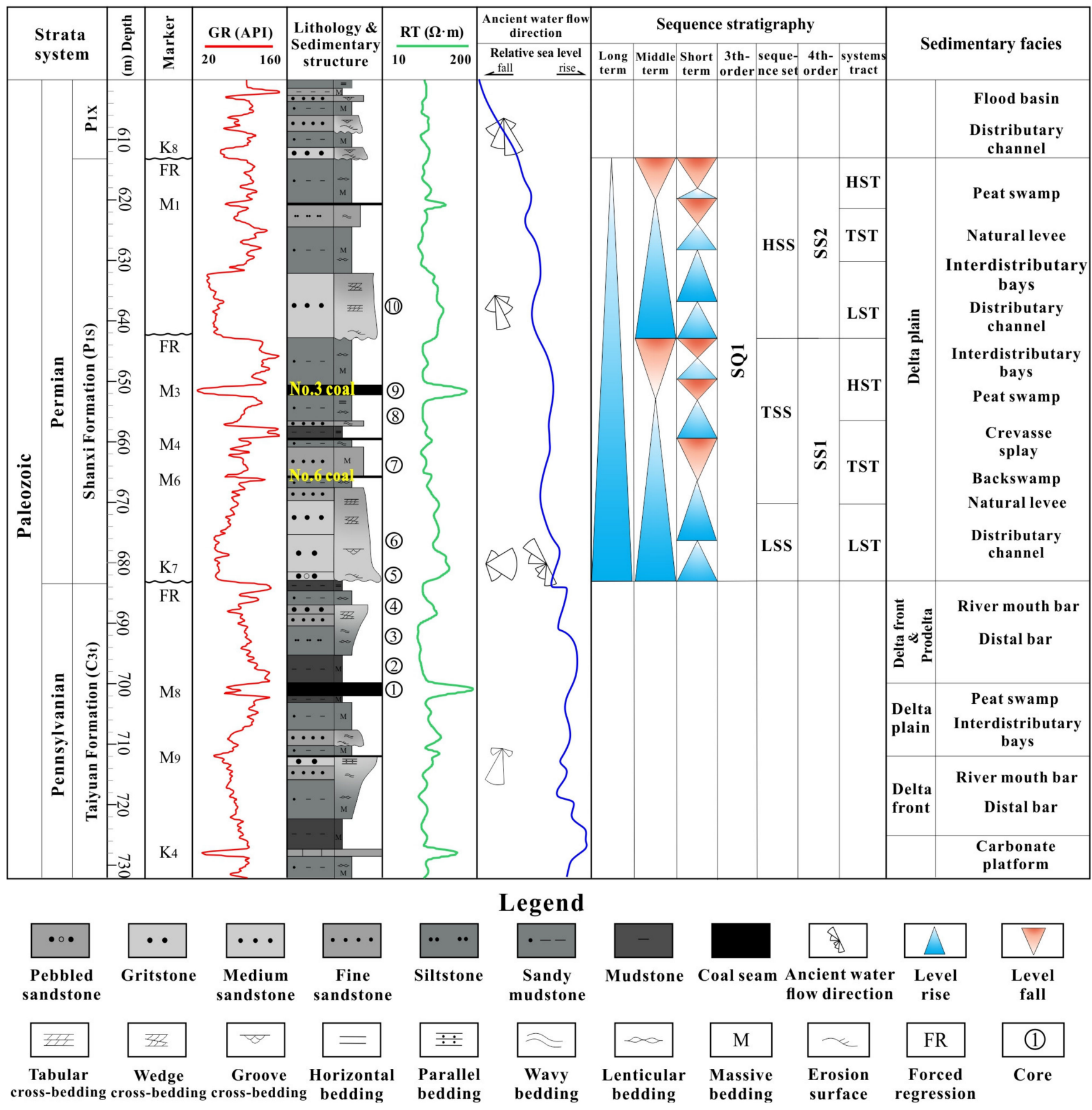

Figure 2. Main stratigraphy, logging curve, lithology, sedimentary facies, sedimentary structure and sequence stratigraphic framework of the coal-bearing strata of well 3-193 in the Qinshui Basin. HSS: high-stand sequence sets; TSS: transgressive sequence sets; LSS: low-stand sequence sets; HST: highstand systems tract; TST: transgressive systems tract; LST: low-stand systems tract; $\mathrm{P}_{1 \mathrm{X}}$ : Xiashihezi Formation. Note that the ancient water flow was modified from Ge et al., 1985.

\subsection{Lithofacies and Sedimentary Facies Types}

Previous studies have shown that the Shanxi Formation in the Yangquan mining area of the Qinshui Basin developed a deltaic sedimentary system under the background of the epicontinental sea [7-9]. According to the outcrops, well logging and core data, the sedimentary facies of coal-bearing series of the Shanxi Formation in the study area can be further subdivided into delta front and delta plain sub-facies, which developed pebbled coarse sandstones, coarse- to fine-grained sandstones, siltstones, mudstones and 
coal seams (Figures 2 and 3 and Table 1). The sandstones mainly developed massive bedding, parallel bedding, wedge cross-bedding and tabular cross-bedding; the mudstones mostly developed massive bedding and horizontal bedding with fossil fragments of plant relics.
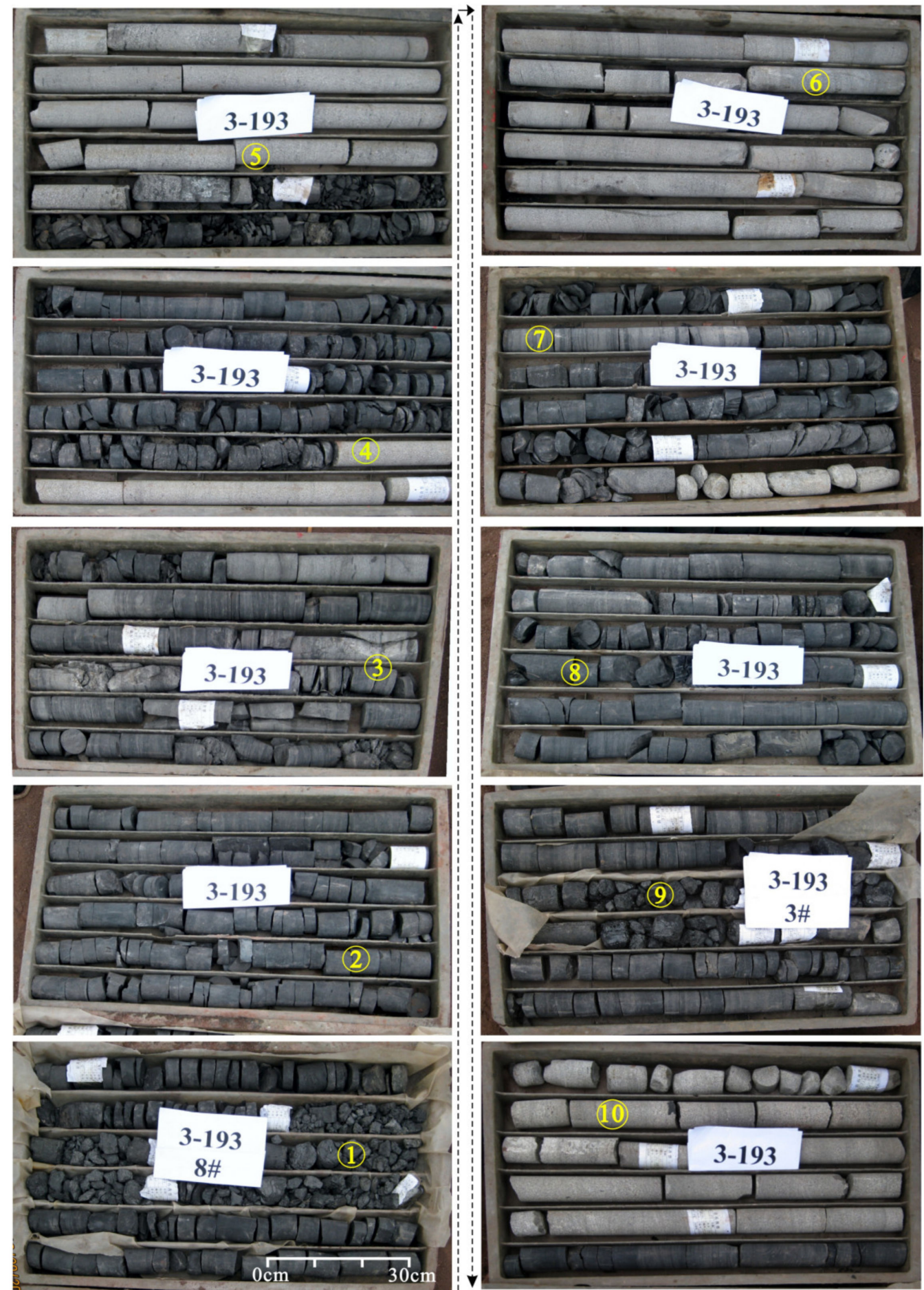

Figure 3. Core information of the coal-bearing series, showing a typical deltaic sedimentary sequence (well 3-193). 
Table 1. Sedimentary facies types, lithofacies and sedimentary structure characteristics of the Shanxi Formation in the study area.

\begin{tabular}{|c|c|c|c|}
\hline $\begin{array}{l}\text { Sedimentary } \\
\text { Facies }\end{array}$ & $\begin{array}{l}\text { Sedimentary } \\
\text { Sub-Facies }\end{array}$ & $\begin{array}{l}\text { Sedimentary } \\
\text { Microfacies }\end{array}$ & Lithofacies and Sedimentary Structure \\
\hline \multirow{8}{*}{$\begin{array}{l}\text { River-dominated } \\
\text { delta }\end{array}$} & \multirow{5}{*}{ Delta plain } & Distributary channel & $\begin{array}{l}10 \text { Greyish to dark grey medium sandstones with tabular } \\
\text { cross-bedding and wedge cross-bedding; poor to moderate } \\
\text { psephicity }\end{array}$ \\
\hline & & Peat swamp & 1,9 Coal and carbonaceous mudstones \\
\hline & & Interdistributary bay & $\begin{array}{l}8 \text { Gray-black mudstones and sandy mudstones with horizontal } \\
\text { bedding }\end{array}$ \\
\hline & & Crevasse splay & 7 Gray fine sandstones and siltstones with massive bedding \\
\hline & & Distributary channel & $\begin{array}{l}\text { 5,6 Greyish to dark grey pebbled gritstone, coarse- to } \\
\text { medium-grained sandstones; tabular cross-bedding and groove } \\
\text { cross-bedding; poor to moderate psephicity }\end{array}$ \\
\hline & \multirow{2}{*}{ Delta front } & River mouth bar & $\begin{array}{l}4 \text { Gray-white medium sandstones and fine sandstones with wedge } \\
\text { cross-bedding }\end{array}$ \\
\hline & & Distal bar & 3 Gray-black siltstones with wavy bedding \\
\hline & Prodelta & & $\begin{array}{c}2 \text { Dark gray-black mudstones and sandy mudstones with massive } \\
\text { bedding and horizontal bedding }\end{array}$ \\
\hline
\end{tabular}

Note: the numbers 1-10 in the table correspond to Figures 2 and 3.

\section{Data and Method}

\subsection{Data Base}

3D seismic data with high signal-to-noise ratio, broad bandwidth and good amplitude fidelity are conducive to the research work of fine characterization of sedimentary facies. In the process of seismic data processing, on the one hand, well-controlled processing techniques, such as well-constrained wavelet deconvolution and phase consistency adjustment, were used to improve the resolution, wave group characteristics and well seismic matching degree. Furthermore, five-dimensional interpolation in offset vector tile (OVT) domain, pre-stack migration and anisotropy correction technologies were used to solve the amplitude distortion caused by the uneven change of offset and azimuth. The 3D seismic grid covers an area of about $20.04 \mathrm{~km}^{2}$, with a common-midpoint (CMP) bin size of $5 \mathrm{~m} \times 10 \mathrm{~m}$. Effective bandwidth of the processed seismic data ranges from 20 to $100 \mathrm{~Hz}$, and the dominant frequency is up to approximately $60 \mathrm{~Hz}$.

\subsection{Method}

Based on high quality 3D seismic data, the corresponding workflow was developed with the integrated interpretation ideas of high-resolution sequence stratigraphy, seismic sedimentology and multiple seismic attribute techniques (Figure 4), mainly including: (1) identifying base level cycle interfaces and delineating high-resolution stratigraphic sequences using logging and core data, and interpreting single-well sedimentary microfacies; (2) seismic data phase analysis and $90^{\circ}$ phase adjustment, establishing seismic-geological isochronous framework through frequency division calibration and tracking isochronous marker layers; (3) petrophysical analysis of the target sequence to determine the correspondence between different lithologies and seismic amplitudes/polarities; (4) making stratal slices on the full-band or frequency-division tuning seismic data, interpreting the seismic sedimentary facies under the constraints of core/logging facies and seismic facies and analyzing the dynamic evolution process of sedimentary facies based on seismic lithological information and seismic geomorphological features; (5) predicting the distribution of sand bodies and the evolution characteristics of sedimentary facies, and further analyzing the control of sedimentation on peat accumulation and coal thickness variation. 


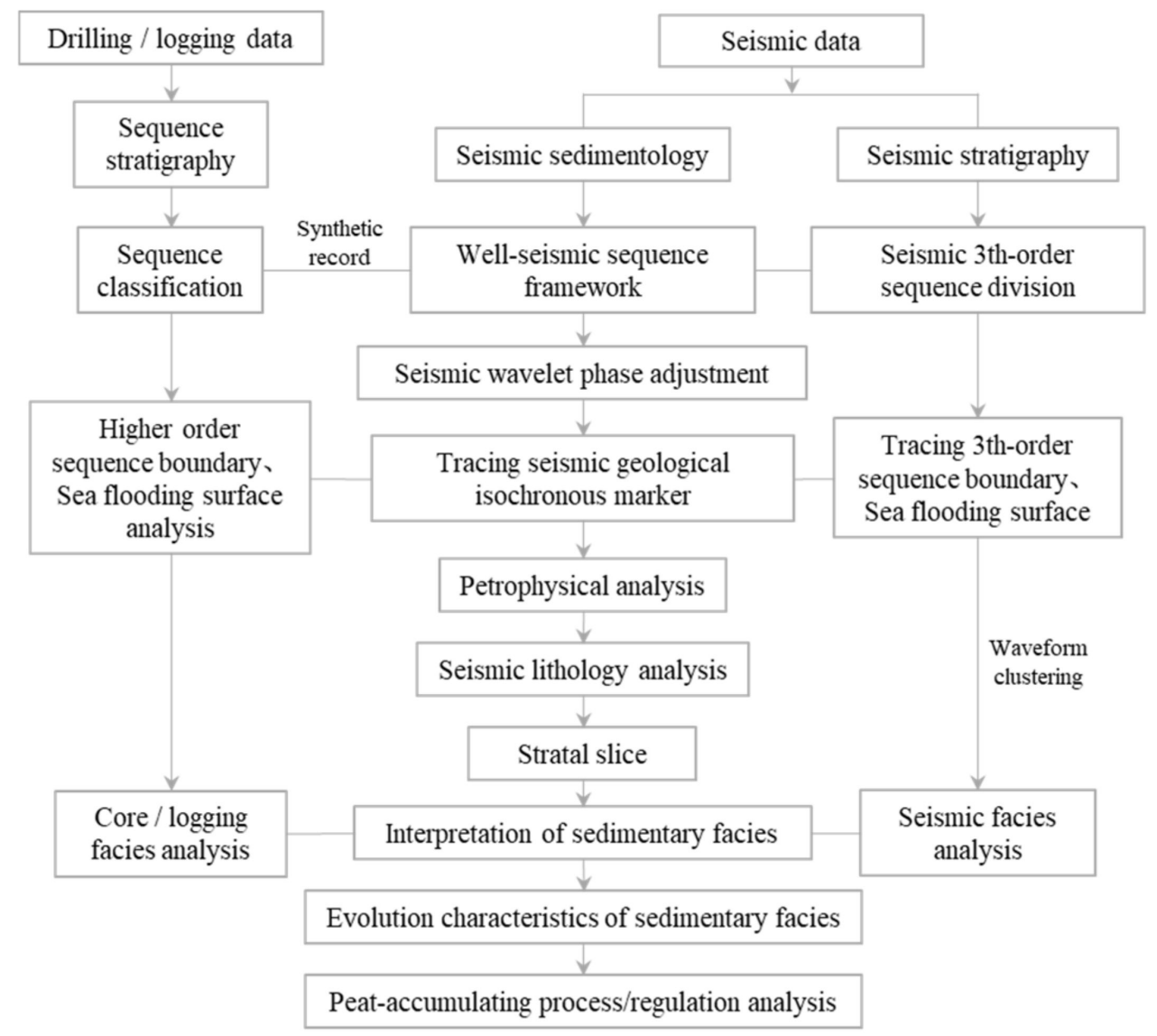

Figure 4. Workflow of integrated seismic-geological interpretation for sedimentary microfacies (referred to Zeng et al., 2012).

\section{Results and Discussion}

\subsection{Isochronous Stratigraphic Frame}

\subsubsection{Sequence Classification}

Identification of Sequence Boundary

The sequence strata can be classified by identifying key interfaces, such as the sequence boundary, transgressive surface and maximum flooding surface [13]. In general, regional unconformities, basal erosional surfaces of the fluvial incised valley, transgression direction switching surfaces and associated paleosols can be taken as the third-order sequence boundaries $[12,13]$. In terms of the Shanxi Formation in the study area, the large-scale distributed sand bodies, such as Beichagou sandstone $\left(\mathrm{K}_{7}\right.$ sandstone) and Luotuobozi sandstone ( $\mathrm{K}_{8}$ sandstone), are generally related to fluvial conditions. For instance, incised valley filling deposits in the low-stand stage and their bottoms are a kind of erosional unconformity, which can be taken as the third-order sequence boundaries. The bottom boundaries of the $K_{7}$ and $K_{8}$ sandstones were regional scour surfaces formed by the strong undercutting action of the river, and there are usually noticeable differences in the depositional environment, terrestrial clastic composition and trace element above and below them [9].

The fourth-order sequence boundaries are often marked by a fluvial erosion surface, coal seam bottom, paleosol layer, etc. $[9,12]$. In the river deltaic sedimentary system, the fourth-order sequence boundaries are often bounded by the fluvial erosion surface, for example, the sandstones bottom surface in the central part of the Shanxi Formation.

\section{Sequence Classification}

In this study, the Shanxi Formation can be divided into a third-order sequence (SQ1) from the bottom of the $K_{7}$ sandstone to the bottom of the $K_{8}$ sandstone, and this third-order 
composite sequence mainly consists of transgressive sequence sets (TSS) and high-stand sequence sets (HSS), with local development of low-stand sequence sets (see Figure 2). The SQ1 sequence was divided into two fourth-order sequences, namely SS1 and SS2. The fourth-order sequences include the low-stand systems tract (LST) represented by the thick channel-belt sands (e.g., $\mathrm{K}_{7}, \mathrm{~K}_{8}$ sandstones) as the incised valley, the transgressive systems tract (TST) represented by the sand-mud interbed and the high-stand systems tract (HST) represented by the coal seam (Figure 2). The No. 3 coal seam, with stable distribution throughout the area, was formed in the HST of the fourth-order sequence, indicating a gradual increase in the increasing rate of the accommodation.

\subsubsection{Seismic-Geological Isochronous Stratigraphic Framework}

Tracing the reflection events on the seismic time section and establishing the isochronous stratigraphic framework are the prerequisites to ensure that the stratal slices are close to the isochronous sedimentary interface $[18,20]$. The sequence boundaries with isochronous significance can be demarcated into the seismic time section by making a synthetic record so that the seismic reflected waves can have clear geological meanings.

The seismic model observations, however, show that the seismic events do not simply reflect the isochronous interface nor the lithologic interface but are controlled by the frequency of the seismic data [22,27]. Using the wavelet transform method, the original seismic data were decomposed into a series of data volumes with different dominant frequencies, and, subsequently, the stable events $\mathrm{K}_{8}, \mathrm{M}_{3}$ and $\mathrm{K}_{7}$ that do not change with the frequency were finally determined through frequency-division calibration. Geologically, incised valley ravinement surface, thin limestone, coal seam, etc., usually have isochronous significance, and their reflection characteristics can be used as good reference isochronous events [21,27]. These isochronous horizons were systematically tracked in the seismic time section, and a seismic-geological isochronous framework was constructed to ensure the reliability of stratal slices, as can be seen in Figure 5.

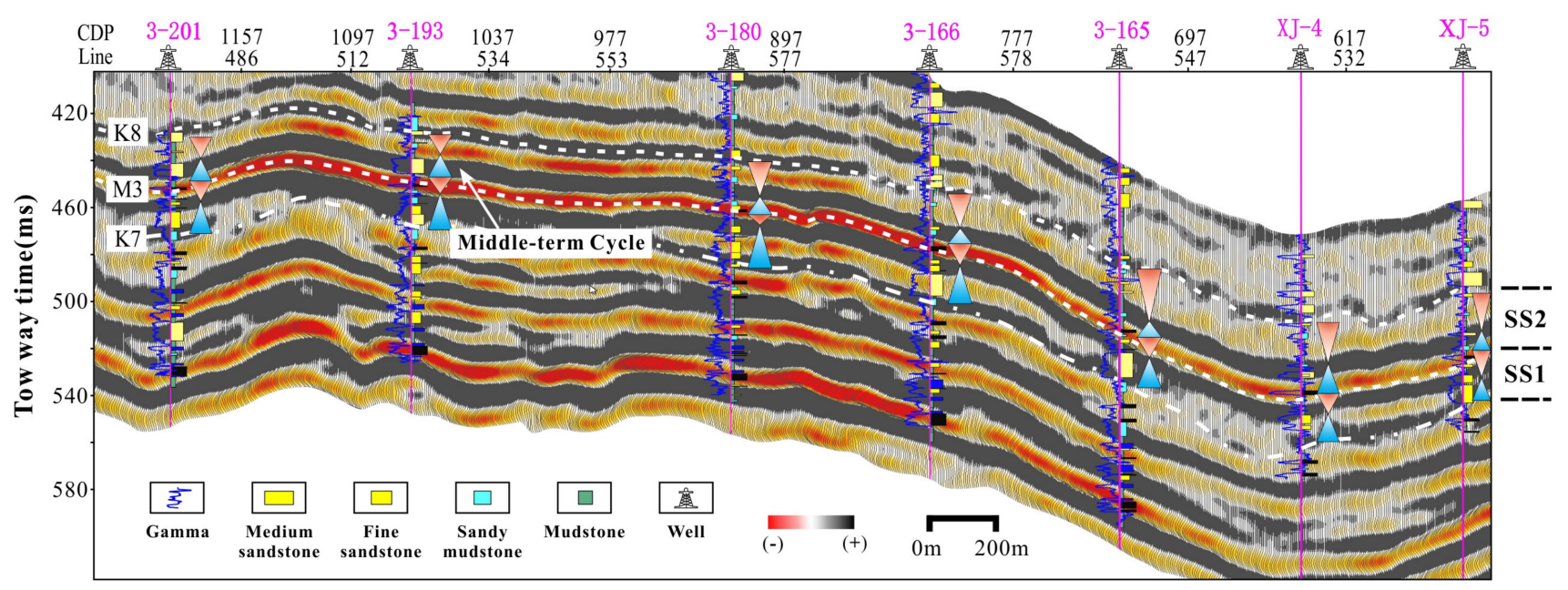

Figure 5. Seismic-geological isochronous stratigraphic frame. The Shanxi Formation was divided into two 4th-order sequences, SS1 and SS2.

\subsection{Petrophysics and Seismic Lithology}

\subsubsection{Petrophysical Analysis}

Petrophysical analysis can effectively obtain the differences in physical properties of rocks with different lithologies in terms of velocity, density, gamma, resistivity, etc., which is a prerequisite for whether seismic data can effectively identify different lithologies [28-30]. The petrophysical analysis results of the logging data (Figure 6) in the study area show that: (1) P-wave velocity of the coal seam is the lowest, about 2200 to $2400 \mathrm{~m} / \mathrm{s}$; (2) the fine-grained siltstones and sandy mudstones have part of the overlapping interval in velocity, but the overall 
velocity of the sandstones is larger than that of the mudstones, and the peak velocity statistic of the sandstones is about $3600 \mathrm{~m} / \mathrm{s}$ and that of the mudstones is about $3200 \mathrm{~m} / \mathrm{s}$; (3) impedance difference between sandstones and mudstones is about $1000 \mathrm{~g} / \mathrm{cm}^{3} \cdot \mathrm{m} / \mathrm{s}$ (density is estimated by $2.5 \mathrm{~g} / \mathrm{cm}^{3}$ ), which provides a petrophysical basis for seismic lithology interpretation.

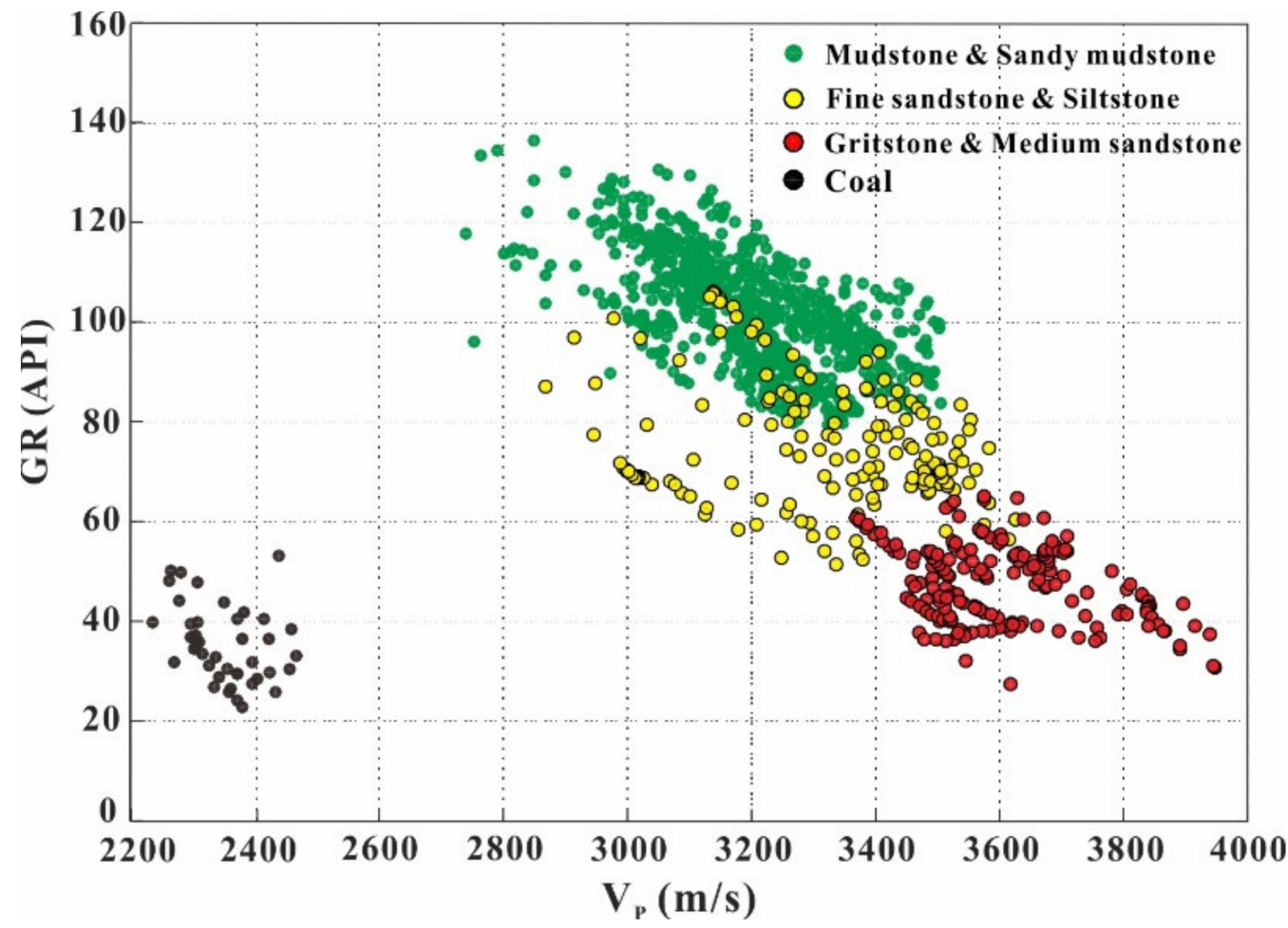

Figure 6. Crossplot of P-wave velocity and gamma of different lithologies in the Shanxi Formation.

\subsubsection{Seismic Lithology Characteristics}

The relationship between lithology and seismic parameters, such as seismic amplitude, polarity and phase, can be established through the analysis of seismic lithology, which provides a basis for subsequent interpretation of stratal slices [18,19]. In the seismicgeological isochronous framework (Figure 5), for the SS1 sequence of the Shanxi Formation, the strong positive amplitude (black event) reflects thick sandstones, while the weaker positive amplitude value represents thin sandstones or muddy sandstones and the negative amplitude (red event) corresponds to mudstone deposits. Most of the wells conform to the above relationships, but some cases do not follow, for example, wells 3-201 and 3-166, which indirectly indicate the complexity of the lithological distribution of coal-bearing series in the study area. Moreover, in view of the corresponding relationship between seismic waveform characteristics (e.g., amplitude and polarity) and lithology in the SS1 sequence, seismic waveform clustering was used to obtain the overall seismic facies characteristics of the sequence and subsequently converted to the sedimentary facies under the constraint of single well.

For the SS2 sequence, there is no clear indication relationship between lithology and amplitude or polarity in the seismic time section (Figure 5). Therefore, the conventional stratal slice technology cannot meet the lithology and sedimentary facies characterization requirements of this sequence. Similar to the studied coal basin, the lithological distribution of the coal-bearing basins in China is much more complex, and, in many cases, sandstones, mudstones, limestones and coal seams coexist, and the wave impedance would be multipolar $[2,18,22]$, especially in areas where thin layers are commonly developed.

In general, coal-bearing strata can be simplified as a layered medium model for geophysical research work, and the thickness of the sedimentary bodies is a key parameter that needs to be considered [31,32]. When the thickness of the sedimentary body is thin, its 
top and bottom positions are difficult to determine due to the limited seismic resolution. It has been shown that it would be difficult and limited to resolve geological bodies smaller than $1 / 4$ wavelength $(1 / 4 \lambda)$ based on the conventional idea of improving seismic resolution [33-35]. Spectrum analysis found that the dominant frequency of the target layer segment is about $60 \mathrm{~Hz}$. Assuming that the formation velocity is $3600 \mathrm{~m} / \mathrm{s}$, the seismic resolution can be estimated by $1 / 4 \lambda$ to be about $15 \mathrm{~m}$. The statistical results of the well data show that the median thicknesses of the sandstones in the SS1 and SS2 sequences are about $16 \mathrm{~m}$ and $7 \mathrm{~m}$, respectively, with a large difference between them (Figure 7). The sandstone thickness of the SS2 sequence is generally less than $1 / 4 \lambda$, and, thus, it may be difficult to meet the needs of fine characterization of the SS2 sequence's thin sand bodies and sedimentary facies by using the amplitude information of the original data.
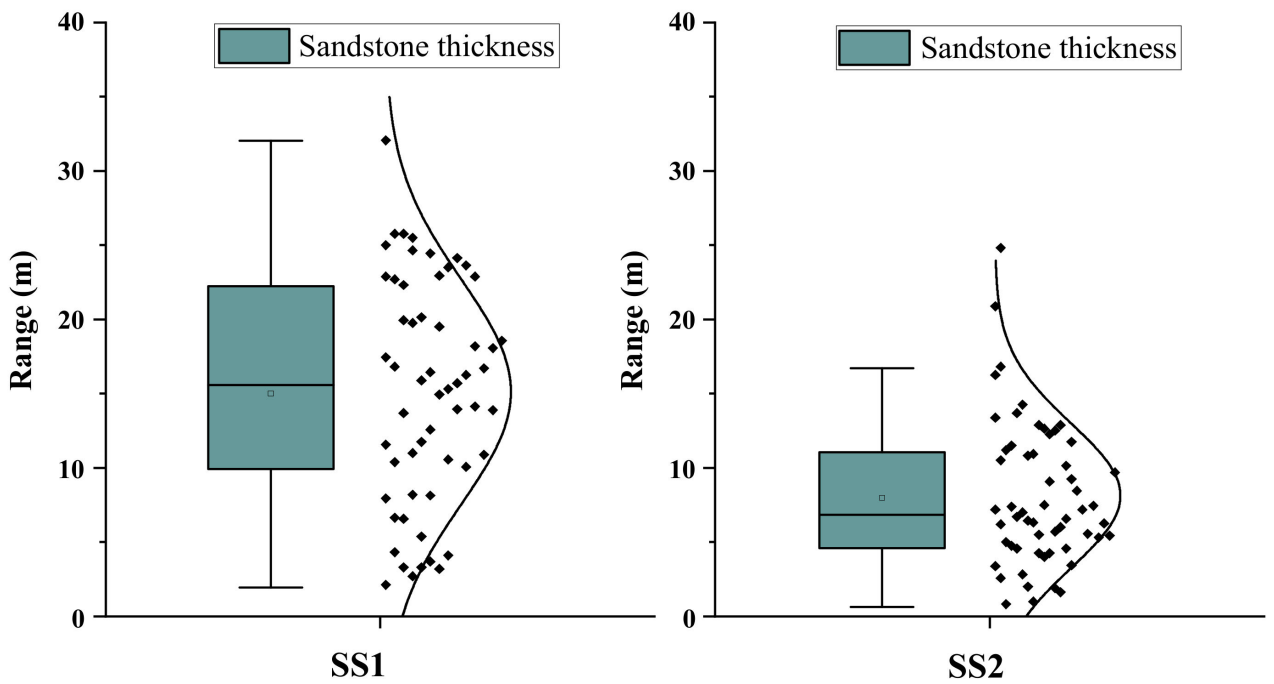

Figure 7. Thickness distribution characteristics of sandstones in the SS1 and SS2 sequences.

It is well known that the amplitude of seismic reflected waves in the layered medium model has a tuning effect, and the amplitude is affected by the thickness of the layered medium [32,36]. It has been reported in the literature that the interpretation of sedimentary facies and the prediction of thin layer thicknesses less than $1 / 4 \lambda$ have been achieved by using the tuning amplitude [34,36,37]. Therefore, an attempt was made to use tuning amplitude to predict the thin sand bodies of the SS2 sequence in the study area, and thus to obtain higher resolution sedimentary facies interpretation results.

In summary, the waveform clustering method was adopted to study the overall characteristics of the sedimentary facies of the SS1 sequence, and the stratal slice technology was used to research the dynamic development process of the sedimentary facies. For the SS2 sequence in the study area, where the thickness of the sand bodies is generally less than $1 / 4 \lambda$, the method of frequency-division amplitude fusion was used to characterize the distribution characteristics of thin sand bodies and sedimentary facies.

\subsection{Coal-Bearing Series Sedimentary Facies and Evolution Characteristics}

\subsubsection{Sedimentary Facies Characteristics of SS1 Sequence}

Waveform clustering mainly uses the similarity of seismic waveform to acquire the spatial distribution of the same geological information and has promising effects in sedimentary boundary detection and sedimentary facies identification [38,39]. The waveform clustering was performed by the self-organizing neural network method, taking $5 \mathrm{~ms}$ downward from the $T_{7}$ reflected wave to $5 \mathrm{~ms}$ upward from the $\mathrm{M}_{3}$ reflected wave as the time window (about $35 \mathrm{~ms}$ ), to obtain the seismic facies characteristics of the SS1 sequence. Subsequently, the seismic facies were reasonably converted to the corresponding sedimentary facies based on the core and $\log$ facies, and the results are shown in Figure 8. 

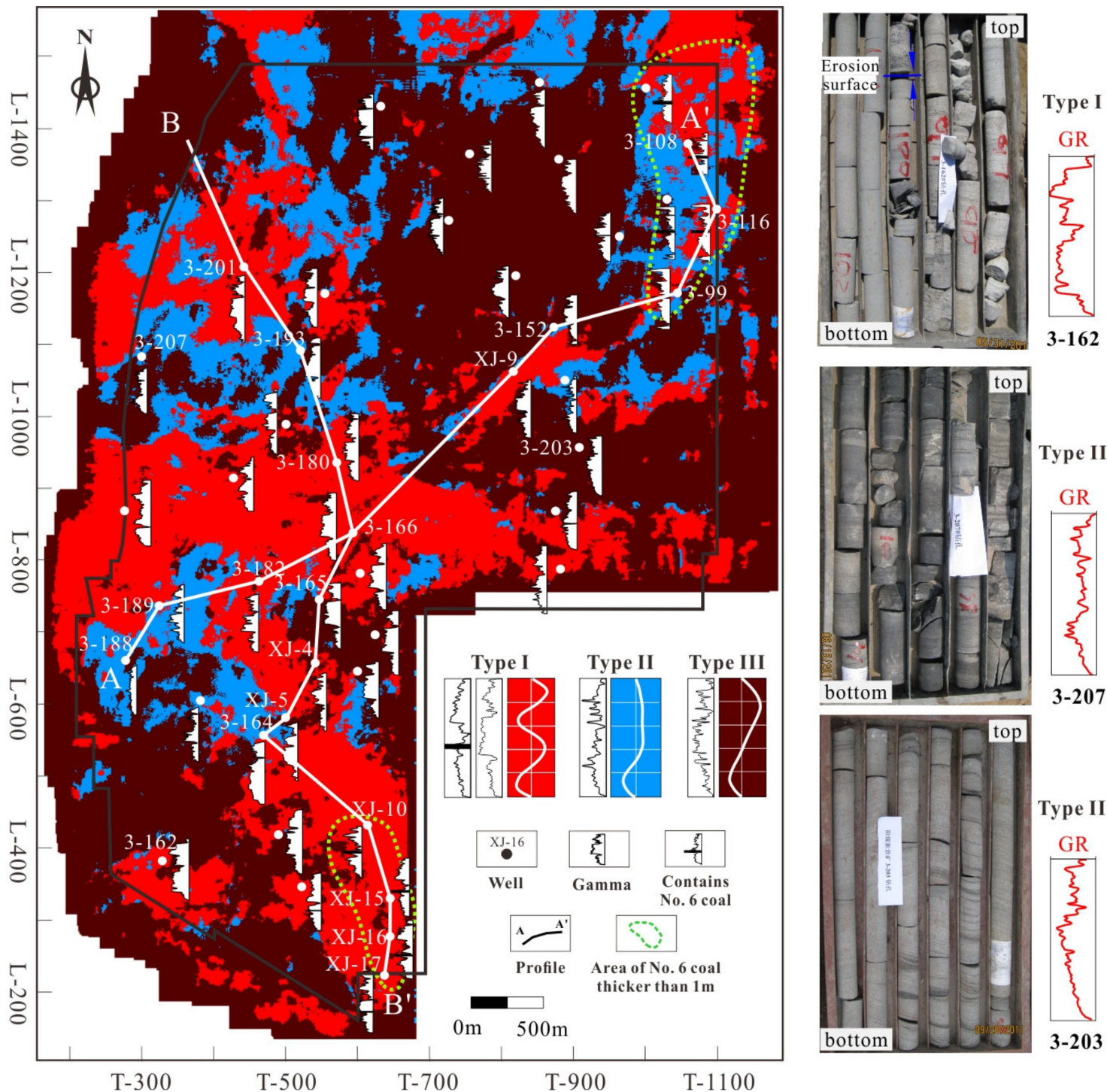

Type III

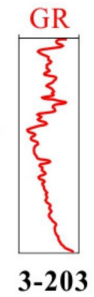

Figure 8. Waveform clustering results of the SS1 sequence, core and logging curve form characteristics. Type I represents distributary channel or backswamp facies. Type II refers to natural levee and crevasse splay facies. Type III reflects river mouth bar face.

Type I (red areas in Figure 8) waveform has the characteristics of higher amplitude with two positive and two negative peaks, corresponding to two kinds of sedimentary facies. One represents distributary channel facies, the gamma curves are box-shaped or bell-shaped and obvious erosion surface could be seen from the core, and sandstones are poorly sorted with low textural maturity. The other refers to backswamp facies, and the logging curves are finger-shaped, representing the local development of No. 6 coal seam (thickness > $1 \mathrm{~m}$ ).

Type II (blue areas in Figure 8) waveform is a negative peak, the gamma curves are mostly straight and the lithology is fine-grained sandstones, siltstones and mudstones, representing the natural levees and crevasse splays. Type III (dark areas in Figure 8) waveform is characterized by one positive and one negative peak, reflecting the river mouth bar deposits of the delta front beneath the SS1 sequence. The gamma curves are funnel-shaped, and the cores show well-sorted sandstones with high textural maturity. The sand bodies are mostly elliptical in plane distribution, and the sand quality is relatively pure due to the stronger effect of longshore current or tidal reformation.

In total, a large amount of debris was transported here during the formation of the SS1 sequence, and the channel sand bodies as a whole bifurcate from west to east and 
southeast. The waveform clustering results are more indicative of the overall developmental characteristics of the sedimentary facies of the SS1 sequence.

\subsubsection{Sedimentary Facies Characteristics of SS2 Sequence}

The net-to-gross ratio, reflecting the proportion of sandstone content in a section of the stratum, is an important parameter for analyzing sand bodies distribution and sedimentary microfacies $[9,40]$. An attempt was made to create stratal slices on the raw seismic data to predict the net-to-gross ratio of the SS2 sequence, but the correlation coefficient was about 0.5 when compared with the well data (Figure $9 a-c)$, and the prediction results were unsatisfactory. This also indirectly indicates that the resolution of the original seismic data may not be able to meet the needs of finely delineating thin sand bodies of the SS2 sequence. Thus, the frequency-division amplitude fusion method was used in order to predict the thin sand bodies. Firstly, the original seismic data were spectrally decomposed to generate low, medium and high frequency data volumes; Then, stratal slices were made on seismic data volumes with different dominant frequencies, and the amplitude values at the well points were cross-analyzed with the net-to-gross ratio to screen out the stratal slices with high correlation. Finally, the selected stratal slices were weighted and fused under the constraint of well data to predict the plane distribution characteristics of the net-to-gross ratio of the SS2 sequence (Table 2).
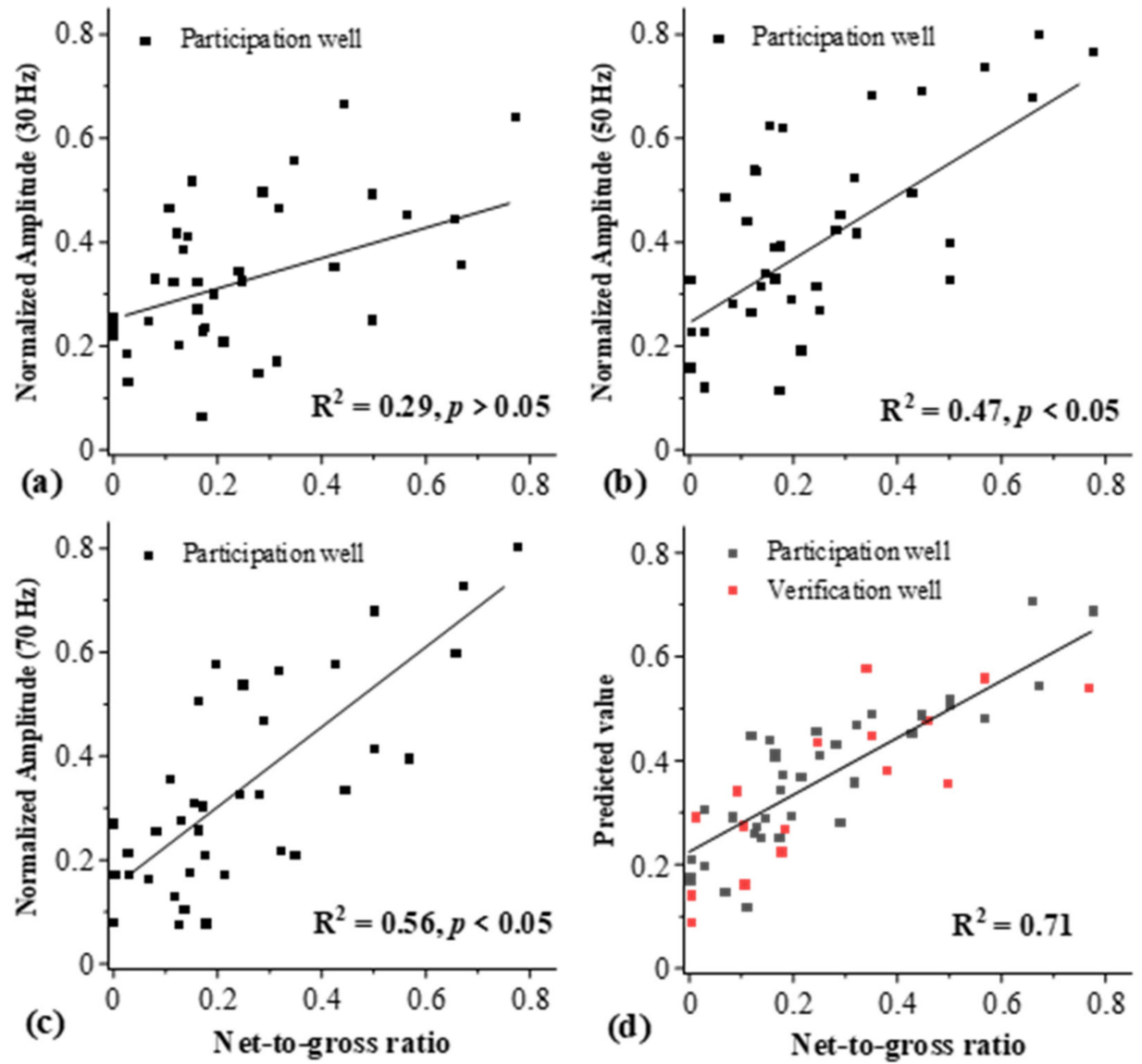

Figure 9. (a-c) are the crossplot results of $30 \mathrm{~Hz}, 50 \mathrm{~Hz}$ and $70 \mathrm{~Hz}$ normalized amplitude and the net-to-gross ratio of SS2 sequence, respectively. (d) Crossplot of the predicted net-to-gross ratio of the SS2 sequence by frequency-division amplitude fusion method vs. the actual value. Note: (1) net-to-gross ratio represents the proportion of sandstones content in a section of the stratum; (2) $R^{2}$ was calculated only by participation wells; (3) the frequency-division amplitudes were normalized to eliminate the effect of order of magnitude. 
Table 2. Results of regression analysis of the net-to-gross ratio and frequency division amplitude in SS2 sequence.

\begin{tabular}{|c|c|c|c|c|c|c|c|c|}
\hline & Coefficients & Standard Error & $p$-Value & Lower 95\% & Upper $95 \%$ & VIF & R Square & F \\
\hline Intercept & -0.089 & 0.046 & 0.002 & -0.254 & -0.064 & - & & \\
\hline $\mathrm{NA}_{50 \mathrm{~Hz}}$ & 0.480 & 0.102 & 0.001 & 0.273 & 0.687 & 1.179 & 0.72 & 47.436 \\
\hline $\mathrm{NA}_{70 \mathrm{~Hz}}$ & 0.592 & 0.099 & 0.000 & 0.392 & 0.795 & 1.179 & & \\
\hline
\end{tabular}

Note: NA is the normalized amplitude; VIF is variance inflation factor.

Since there is no correlation between the $30 \mathrm{~Hz}$ amplitude and the target sequence net-to-gross ratio ( $p>0.05$, as shown in Figure 9a), it was not involved in the regression analysis. Meanwhile, the $50 \mathrm{~Hz}$ and $70 \mathrm{~Hz}$ amplitudes were used to build the SS2 sequence net-to-gross ratio prediction model, as shown in Equation (1). It can be seen from Table 2 that the model passed the $F$ test $(F=47.436)$, and the $R^{2}$ of the model was 0.72 , which means that $\mathrm{NA}_{50 \mathrm{~Hz}}$ and $\mathrm{NA}_{70 \mathrm{~Hz}}$ can explain $72 \%$ of the variation in the net-to-gross ratio of the SS2 sequence. In addition, the multicollinearity test of the model found that the VIF values in the model were all less than 5 , suggesting that there was no collinearity problem and the model was good.

$$
\mathrm{Y}_{\mathrm{SS} 2}=-0.089+0.480_{\mathrm{x} 1}+0.592_{\mathrm{x} 2}
$$

where $\mathrm{Y}_{\mathrm{SS} 2}$ represents the net-to-gross ratio of SS2 sequence; $x_{1}$ is the normalized amplitude of $50 \mathrm{~Hz} ; \mathrm{x}_{2}$ is the normalized amplitude of $70 \mathrm{~Hz}$.

The correlation coefficient between the net-to-gross ratio predicted by the frequencydivision amplitude fusion method and the actual values reaches 0.71 , and most of the verification wells fall within the predicted trend (Figure 9d), suggesting that the prediction results are credible. The method of frequency-division amplitude fusion has improved the ability of seismic data to identify thin sand bodies in coal-bearing strata. However, the stratigraphic structure of the study area is complex, and some factors were not considered in the seismic lithology analysis, such as the influence of the surrounding rock on the reflected signal [37], and there is still room for improvement in prediction accuracy.

The statistical results of well data show that the net-to-gross ratio of distributary channels, natural levees and interdistributary bays in the Shanxi Formation are 0.5-1, $0.3-0.5$, and $0-0.3$, respectively. Taking the net-to-gross ratio as a sensitive parameter to reflect sedimentary facies, the development characteristics of the sedimentary facies of the target sequence were comprehensively interpreted under the constraints of the regional depositional environment and single-well sedimentary facies (Figure 10a,b). The delta plain sub-facies developed in the study area during the formation of the SS2 sequence. The distribution of sand bodies is dominated by north-south trend, and the sand bodies in the north are thicker (Figure 10a), indicating that the sediments continuously prograde toward the center of the basin from north to south. Distributary channels are developed in the eastern, northwestern and central-southern parts, and the sediments are mainly medium sandstones and fine sandstones. Meanwhile, crevasse-splay deposits are developed locally. There are natural levees on both sides of the distributary channels, and the sediments are fine sandstones and siltstones. Other parts of the study area are mostly developed interdistributary bays, which connected with the sea and had weak hydrodynamics. The sediments in these parts are mainly mudstones, with a small amount of siltstones. 

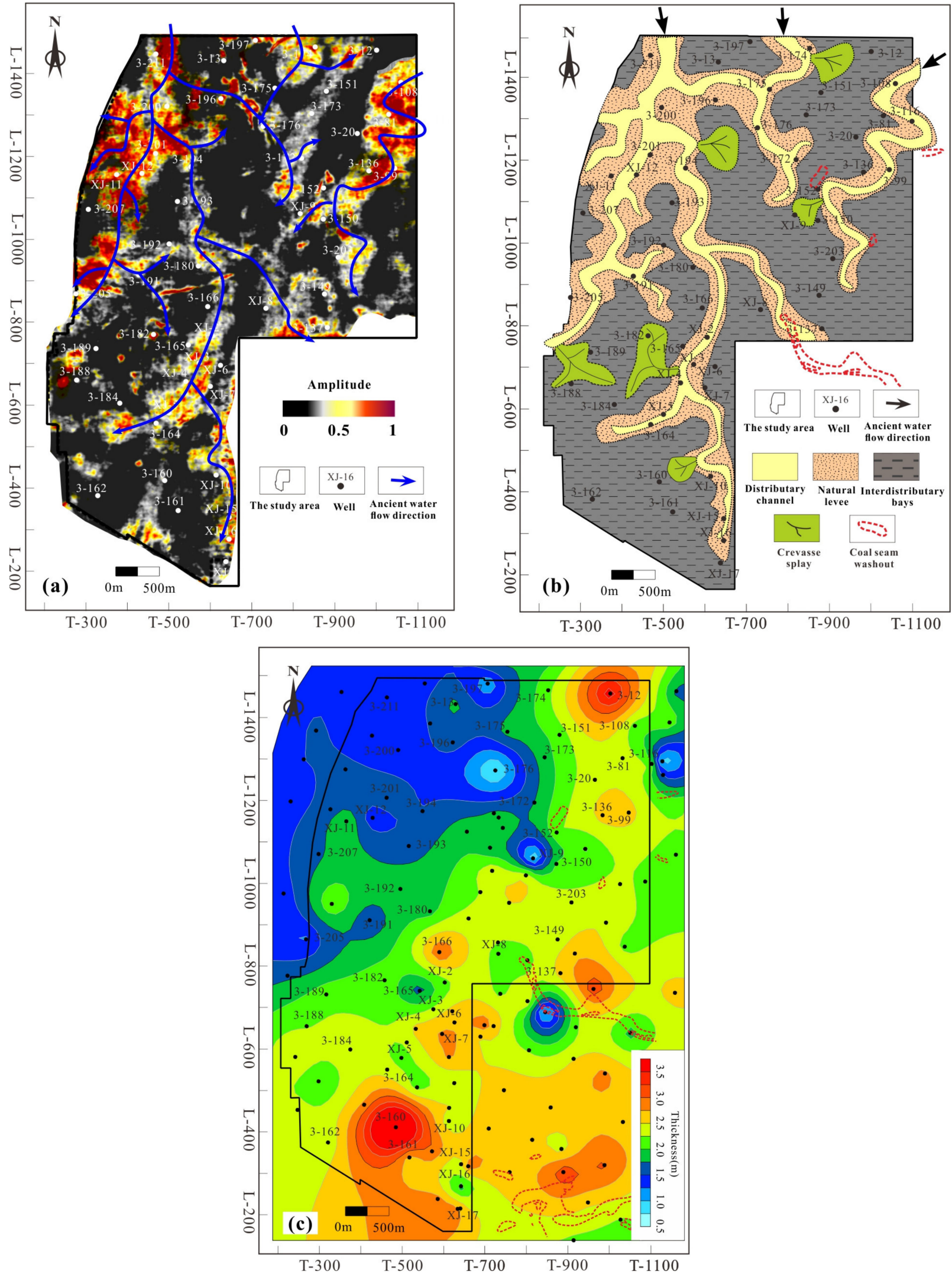

Figure 10. (a) SS2 sequence frequency-division amplitude fusion results; (b) sedimentary microfacies of the SS2 sequence; (c) thickness of the No. 3 coal seam obtained by Kriging interpolation. 
Notably, this study found that the thickness of the No. 3 coal seam has a good correspondence on the plane with the distribution of the distributary channels of the SS2 sequence. Comparing the thickness of the No. 3 coal seam and sedimentary facies maps (Figure 10b,c), it can be seen that the coal thickness in the northwestern part of the study area is significantly thinner (average less than $1.5 \mathrm{~m}$ ), which coincides well with the distribution position and extension direction of the sand bodies of the distributary channels. The cores data show that the direct roofs of the No. 3 coal seams in most wells in the northwest regions are coarse- to medium-grained sandstones, which are generally thicker than those of other areas. This is clear evidence that the coal seam had been thinned by river erosion. In addition, there are thin coal seams with banded or spotted distribution in the northeast and central parts (such as the regions where wells 3-116, 3-152 and XJ-9 are located), which is presumed to be caused by the lateral erosion of the distributary channels on the concave bank.

\subsubsection{Evolution Characteristics of Sedimentary Facies}

On the basis of the seismic-geological isochronous stratigraphic framework, continuous stratal slices of the Shanxi Formation in the study area were made to obtain the lithological distribution characteristics of the coal-bearing series and the dynamic evolution process of sedimentary facies. A total of thirty-six stratal slices were made between the $\mathrm{K}_{7}$ and $\mathrm{K}_{8}$ isochronous layers, and four typical slices were selected for description and interpretation, namely slice 1 to slice 4 from bottom to top. It should be noted that slice 1 to slice 3 were acquired on the phase-rotated data volume of the original seismic data, mainly to interpret the lithological distribution characteristics of the SS1 sequence in different periods, while slice 4 was acquired on the frequency-division seismic data volume by attribute fusion technique to better characterize the thin sand bodies in the SS2 sequence.

\section{Stratal Slices Description and Interpretation}

The stratal slice 1 reflects the sedimentary characteristics of the lower part of the SS1 sequence. The eastern part of the slice shows that the distributary channels (red areas in Figure 11a, slice 1) began to bifurcate to form two major branches, and the sand bodies distributed in an east-west direction (Figure 11). The blue areas are relatively concave bay areas, and there are sporadic deposits of river mouth bar and distal bar. This slice mainly shows the depositional environment of the delta plain and delta front developed in the deltaic system.

Stratal slice 2 reflects the sedimentary characteristics of the middle part of the SS1 sequence, and the sand bodies are characterized by widening from west to east. It can be seen that the distributary channels (red areas in Figure 11a, slice 2) further advance to the southeast and northeast. At the same time, the bifurcation and swing at the end of the river were obviously enhanced, and the river mouth bars were developed (Figure 11). This progradation feature is most obvious between well 3-189 and 3-152 in profile A$\mathrm{A}^{\prime}$ (Figure 12), and the sand bodies in different periods were arranged to the east in imbricate arrangement. Profile B- $\mathrm{B}^{\prime}$ shows that the sand bodies were vertically incised and superimposed, indicating that these areas have strong hydrodynamics, and some river mouth bars or early channel sand bodies may be washed away by downward erosion (Figure 13). Abandoned channels were identified in the logging data of XJ-4 and XJ-5, indicating that the channels migrated frequently. This slice mainly shows the depositional environment of the delta plain. 


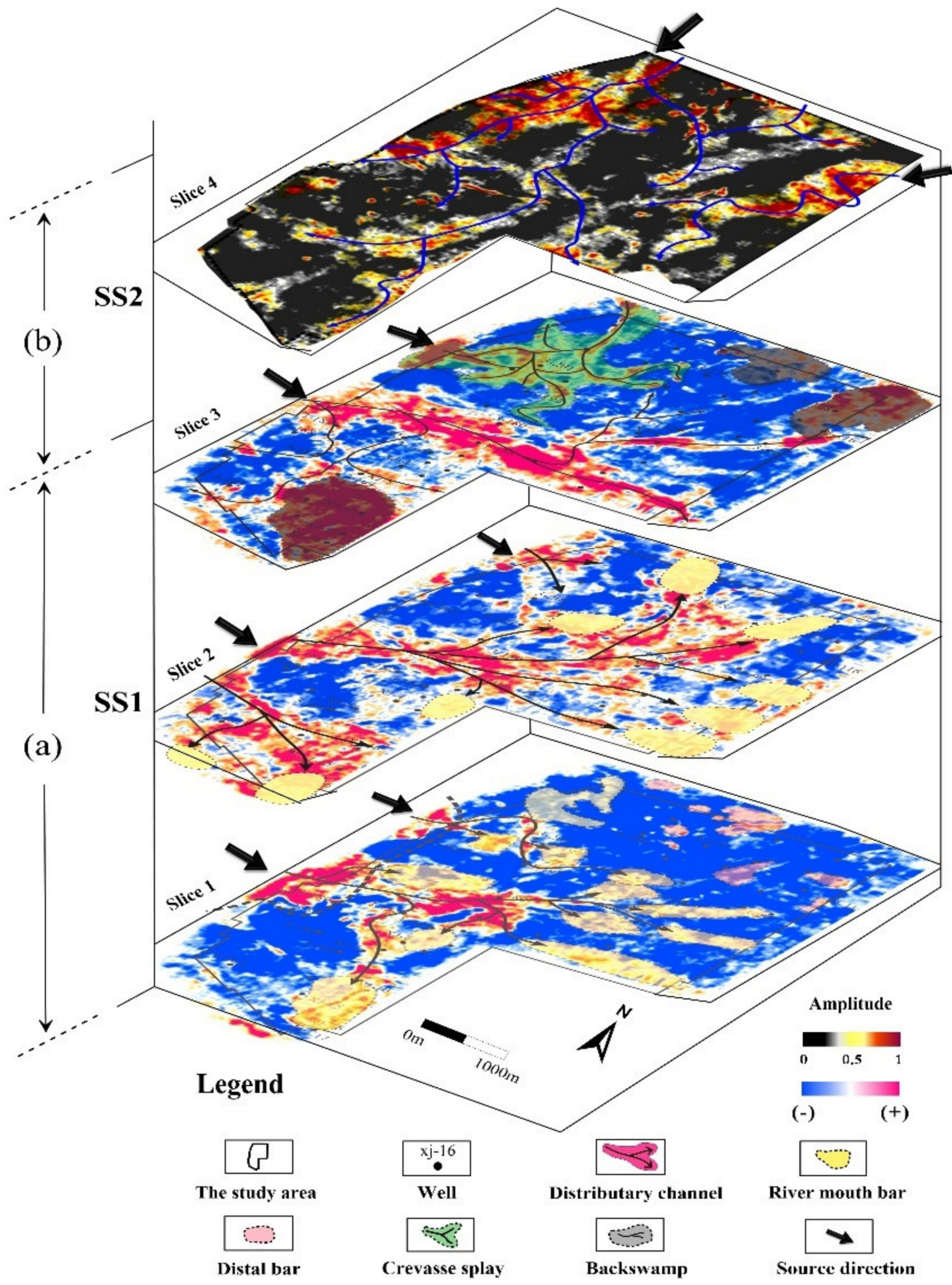

Figure 11. Interpretations of typical stratal slices of the SS1 sequence (a) and SS2 sequence (b) in the Shanxi Formation. Note that slices 1-3 reflect the sedimentary characteristics of the SS1 sequence and were made on the basis of the phase rotation of the original seismic data. Slice 4 reflects the SS2 sequence, obtained by the frequency-division amplitude fusion method. 

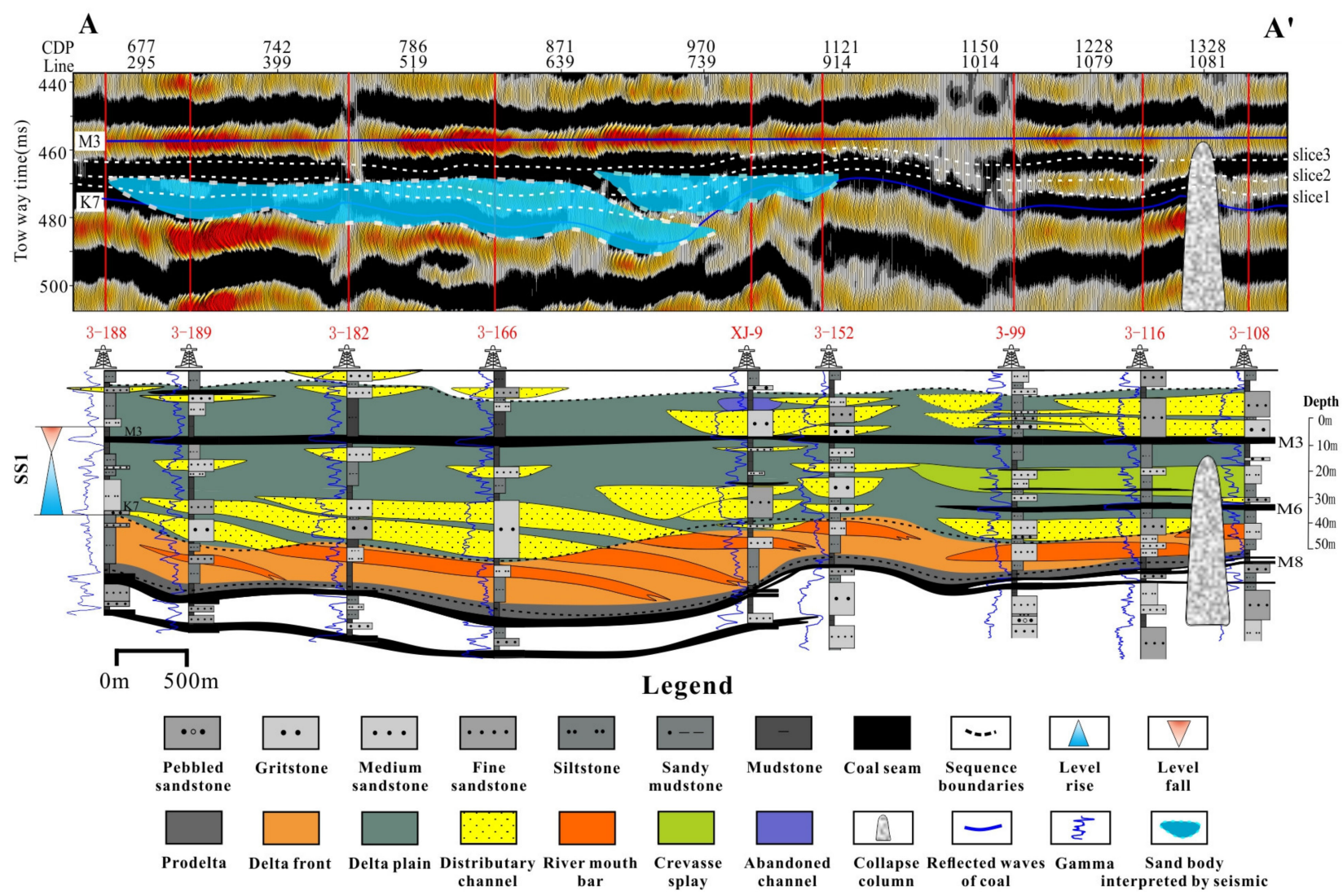

Figure 12. Seismic-geological comprehensive interpretation of sand bodies distribution and sedimentary facies ((A-A') profile).

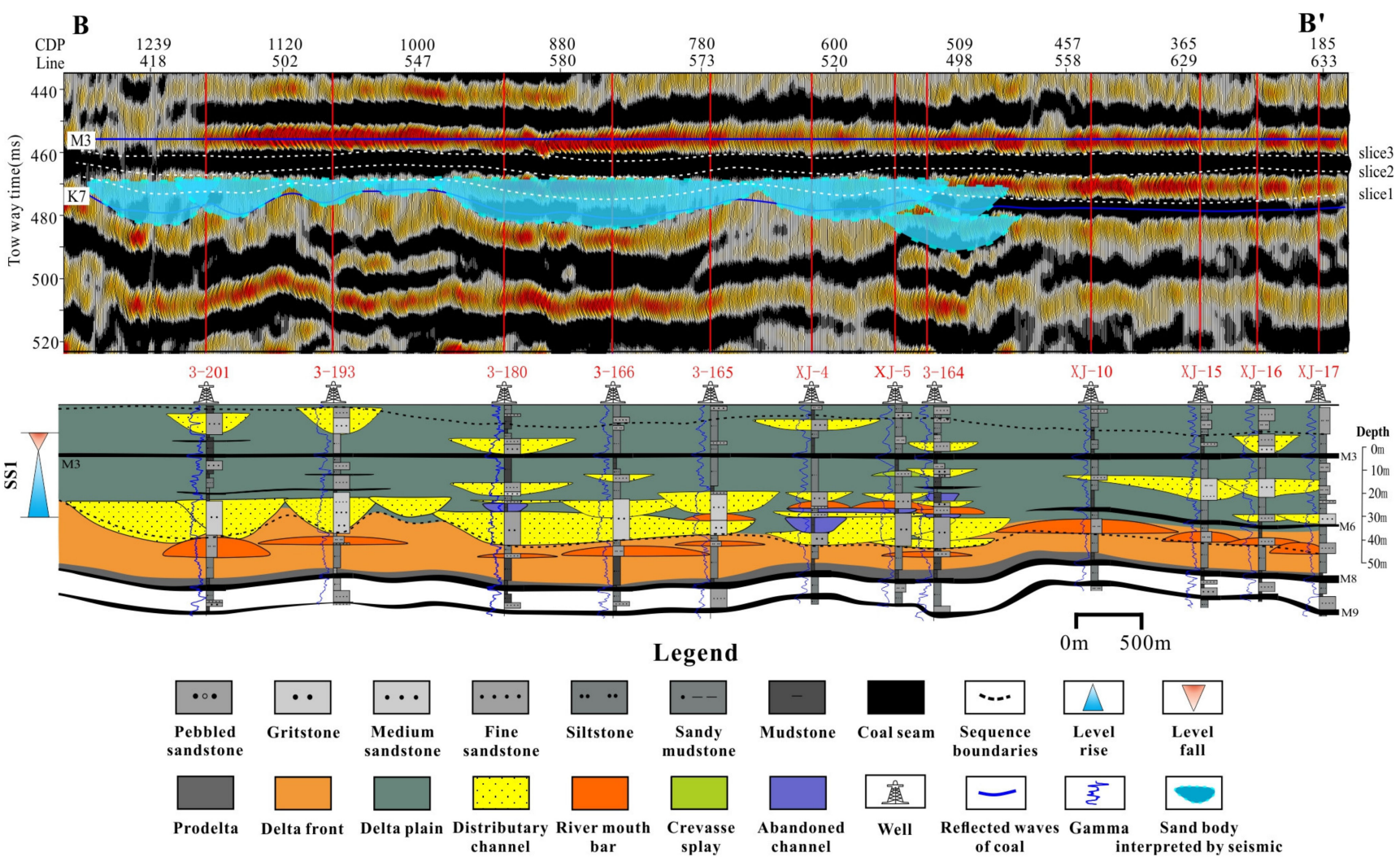

Figure 13. Seismic-geological comprehensive interpretation of sand bodies distribution and sedimentary facies ((B-B' $\left.\mathbf{B}^{\prime}\right)$ profile). 
Stratal slice 3 mainly reflects the depositional characteristics of the late formation stage of the SS1 sequence. In the northeast and southeast, there are three flaky backswamp depositional areas, which are characterized by the deposition of the No. 6 coal seam, and the coal thickness is generally greater than $1 \mathrm{~m}$, and even more than $3 \mathrm{~m}$ in the northeast part of the area (Figure 11a, slice 3). In addition, the logging curve shape and geomorphological features suggest that crevasse splays are developed in the northwest part of the area with a relatively complete morphology. It is worth noting that, due to the complex lithological distribution of coal-bearing strata, sandstones, mudstones, limestones and coal seams coexist in most cases, and the large differences in impedance between coal seams and surrounding rocks may cause variations in reflected wave amplitudes. Therefore, the local areas that do not conform to the geological laws need to be corrected in combination with well data during the interpretation of stratal slices.

Stratal slice 4 comprehensively reflects the depositional characteristics of the SS2 sequence. This slice shows that the sand bodies are distributed in a north-south direction as a whole and are thick in the north and thin in the south, and the sand bodies distribution direction is obviously different from the east-west oriented sand bodies of the SS1 sequence (Figure 11b, slice 4). This phenomenon was supposed to be mainly caused by the diversion of rivers back to the study area. Combined with the sandstone percentage of SS2 sequence and the logging curve characteristics, stratal slice 4 was interpreted as sedimentary microfacies, such as distributary channels, natural levees and crevasse splays.

\section{Sedimentary Evolution Characteristics of Shanxi Formation}

The comprehensive analysis results of cores, log curves characteristics and seismic interpretation results indicate that the Shanxi Formation in the study area developed a deltaic sedimentary system, mainly with delta plain sub-facies (Figure 14). In the early stage of the formation of the SS1 sequence, the base level rose slowly and the sediments supply was sufficient. The sediments show the characteristics of high energy and high construction during the process of progradation from west to southeast and northeast. The mouth bars in the delta front are relatively developed, and the upper distributary channel sand bodies are closely superimposed, with fewer muddy interlayers. During the early delta construction stage, the palaeomires of No. 6 coal seams were developed in the backswamp environment.

In the later stage of the SS1 sequence, it was speculated that the sediments supply was significantly reduced due to the diversion of the river, resulting in a smaller distribution scale of sand bodies. Eventually, the delta was abandoned and the interdistributary bays were slowly filled and silted up to form a vast platform, and then palaeomires were developed, where the precursor peats of the No. 3 coal seam were accumulated in a large area.

The sand bodies distribution direction of the SS2 sequence is obviously different from that of the SS1 sequence (Figure 14), which is presumed to be caused by the diversion of rivers and returning to the research area. This finding is consistent with previous studies on the change of paleocurrent direction in the middle stage of the formation of the Shanxi Formation in the entire Yangquan mining area [7,41]. After the accumulation of the No. 3 coal seam, the delta began to enter the constructive stage again. The SS2 sequence is composed of several cycles, with a finer grain size upward, and developed sedimentary microfacies, such as distributary channels, interdistributary bays, natural levees and crevasse splays. To sum up, the Shanxi Formation in the study area developed a deltaic sedimentary system and underwent the constructive-abandoned-constructive development stage. 


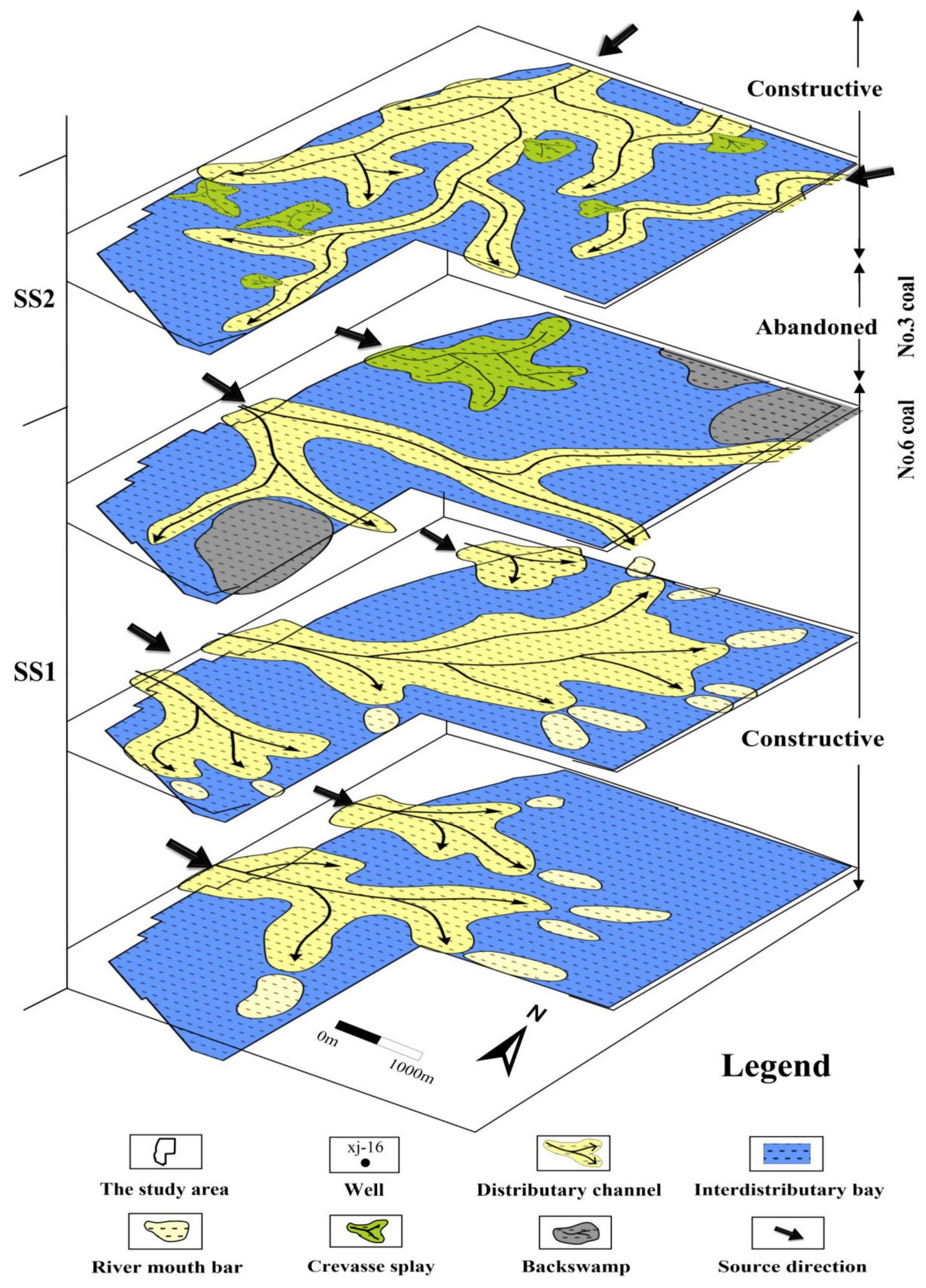

Figure 14. Sedimentary evolution process of the Shanxi Formation. Note that the Shanxi Formation was divided into SS1 and SS2 sequences.

\subsection{Peat-Accumulating Regularity of Main Coal Seams}

Peat accumulation often occurs in a certain evolution stage and specific part of the sedimentary basin and shows a certain regularity in time and space [9,12,42]. Usually, factors such as paleotectonic, paleogeography, paleoclimate and the peat-forming plants all have certain influences on peat accumulation $[1,2,5,43,44]$. Nevertheless, in this study, we 
only focused on the control of sedimentation on the accumulation of the No. 3 coal seam and the No. 6 coal seam in the Shanxi Formation.

The palaeomires of No. 6 coal seam were accumulated in the delta construction stage and developed in the backswamp of the delta plain, which is conducive to the reproduction of peat-forming plants and the accumulation of peat. The distribution of the No. 6 coal seam is restricted by the distributary channels, and the extension direction is usually consistent with the distributary channels. At the same time, the river diversion would destroy the continuous accumulation of peat, resulting in a large variation in the thickness of the No. 6 coal seam in this environment, with coal thickness ranging from 0 to $3.1 \mathrm{~m}$, average $1.4 \mathrm{~m}$ and only locally mineable (see Figure 14).

There are many factors that affect the thickness variation of the No. 3 coal seam, mainly due to the depositional environment during the peat accumulation period and the epigenetic erosion of the river. The No. 3 coal seam is mainly distributed on the land side of the delta plain and was formed near the maximum flooding surface. The higher rate of peat accumulation rate was balanced with the higher growth rate of the accommodation, which makes the No. 3 coal seam thicker, with a thickness of 0.5 to $4.3 \mathrm{~m}$, an average of $2.3 \mathrm{~m}$.

The abandoned stage of the delta during the formation of the SS1 sequence was very favorable for peat accumulation. On the abandoned delta lobes, because of differential compaction and imbalanced crustal subsidence, the terrain became low-lying to form an interdistributary bay environment that connected with the sea. The filling and silting of the interdistributary bays connected the peat-forming swamp on the abandoned delta lobes, providing an ideal place for the accumulation of precursor peat of the No. 3 coal seam. Since the early formation of the SS2 sequence, the delta entered the constructive stage again, and the distributary channels caused local erosion of the deposited No. 3 coal seam (Figure 10). The thin and unminable coal zones caused by river erosion are controlled by the location of the channels and their extension direction.

\section{Conclusions}

The Shanxi Formation in the study area mainly developed delta plain sub-facies, including sedimentary microfacies, such as distributary channels, natural levees, interdistributary bays and crevasse splays, and it can be divided into a third-order sequence, SQ1, and two fourth-order sequences, SS1 and SS2. The sedimentary filling direction changed from the west-east direction of the SS1 sequence to the north-south direction of the SS2 sequence, and the delta development underwent a constructive-abandoned-constructive stage.

The palaeomires of the No. 6 coal seam in the Shanxi Formation developed in the natural levee and backswamp depositional environment, and their distribution was controlled by the distributary channels. The delta in the later stage of the SS1 sequence was abandoned, and the filling and silting of the interdistributary bays provided an ideal place for the precursor peat accumulation of the No. 3 coal seam. The higher peat accumulation rate was balanced with the growth rate of the accommodation, resulting in the formation of a thicker No. 3 coal seam over a wide area. Moreover, the No. 3 coal seam was locally thinned by the epigenetic erosion of the river, and the thin coal zone caused by river erosion is controlled by the location of the distributary channels.

By combining static and dynamic analysis methods, such as waveform clustering, stratal slice and frequency-division amplitude fusion, the planar distribution of the sedimentary facies and sedimentary evolution process of coal-bearing series in the study area can be finely delineated with the comprehensive use of multi-source data, such as cores, logs and seismic data. On the basis of tuning amplitude, the stratal slice technique has been improved to enhance the prediction accuracy of thin sand bodies in the fourth-order sequence, extending the application of seismic sedimentology in coal-bearing strata. Meanwhile, this research can provide a reference for the study of sedimentary facies before and after peat accumulation in coal-bearing strata under a marine-continental transitional environment. 


\begin{abstract}
Author Contributions: Conceptualization, S.C. and Q.C.; methodology, S.C.; software, B.L.; validation, B.L. and Q.C.; formal analysis, B.L.; investigation, S.C.; resources, Y.L., Z.Y. and Z.L.; data curation, Z.Y. and Z.L.; writing—original draft preparation, B.L.; writing-review and editing, S.Z.; supervision, S.Z. and S.C.; project administration, S.C.; funding acquisition, S.Z. and S.C. All authors have read and agreed to the published version of the manuscript.

Funding: This research was funded by the National Natural Science Foundation of China (grant no. 42102212), the Natural Science Foundation of Shanxi Province (grant no. 201901D211005), the unveiling projects of the Department of Science and Technology of Shanxi Province (20191101018), Shanxi Province Science and Technology Major Project (20191102001) and the Research and Development Project of Yangquan Coal Industry (Group) Co., Ltd. (GY18027).
\end{abstract}

Data Availability Statement: Data available on request due to restrictions of privacy or ethical.

Conflicts of Interest: The authors declare no conflict of interest.

\title{
References
}

1. Dai, S.; Bechtel, A.; Eble, C.F.; Flores, R.M.; French, D.; Graham, I.T.; Hood, M.M.; Hower, J.C.; Korasidis, V.A.; Moore, T.A.; et al. Recognition of peat depositional environments in coal: A review. Int. J. Coal Geol. 2020, 219, 103383. [CrossRef]

2. Shao, L.; Wang, X.; Lu, J.; Wang, D.; Hou, H. A Reappraisal on Development and Prospect of Coal Sedimentology in China. Acta Sedimentol. Sin. 2017, 35, 1016-1031. [CrossRef]

3. Wang, Y.; Zhu, Y.; Liu, Y.; Chen, S. Reservoir characteristics of coal-shale sedimentary sequence in coal-bearing strata and their implications for the accumulation of unconventional gas. J. Geophys. Eng. 2018, 15, 411-420. [CrossRef]

4. Cecil, C.B. An overview and interpretation of autocyclic and allocyclic processes and the accumulation of strata during the Pennsylvanian-Permian transition in the central Appalachian Basin, USA. Int. J. Coal Geol. 2013, 119, 21-31. [CrossRef]

5. Çelik, Y.; Karayigit, A.I.; Oskay, R.G.; Kayseri-Özer, M.S.; Christanis, K.; Hower, J.C.; Querol, X. A multidisciplinary study and palaeoenvironmental interpretation of middle Miocene Keles lignite (Harmancik Basin, NW Turkey), with emphasis on syngenetic zeolite formation. Int. J. Coal Geol. 2021, 237, 103691. [CrossRef]

6. Opluštil, S.; Lojka, R.; Pšenička, J.; Yilmaz, Ç.; Yilmaz, M. Sedimentology and stratigraphy of the Amasra coalfield (Pennsylvanian), NW Turkey-New insight from a $1 \mathrm{~km}$ thick section. Int. J. Coal Geol. 2018, 195, 317-346. [CrossRef]

7. Ge, B.; Yin, G.; Li, C. A preliminary study on sedimentary environments and law of coal-bearing formation in Yangquan, Shanxi. Acta Sedimentol. Sin. 1985, 3, 33-44. [CrossRef]

8. Jiao, X.; Wang, Y. Depositional environments of the coal-bearing strata and their controls on coal seams in the Yangquan mining district, Shanxi. Sediment. Facies Palaeogeogr. 1999, 19, 30-39.

9. Shao, L.; Dong, D.; Li, M.; Wang, H.; Wang, D.; Lu, J.; Zheng, M.; Cheng, A. Sequence-paleogeography and coal accumulation of the Carboniferous-Permian in the North China Basin. J. China Coal Soc. 2014, 39, 1725-1734. [CrossRef]

10. Cai, Y.; Liu, D.; Yao, Y.; Li, J.; Qiu, Y. Geological controls on prediction of coalbed methane of No. 3 coal seam in Southern Qinshui Basin, North China. Int. J. Coal Geol. 2011, 88, 101-112. [CrossRef]

11. Chang, S.; Chen, Q.; Liu, D.; Pan, Y.; Gui, W.; Liu, Z.; Cao, L.; Feng, A. Preliminary discussion on coal bed methane storage unit and its seismic geology comprehensive identification method. J. China Coal Soc. 2016, 41, 57-66. [CrossRef]

12. Ren, J.; Wang, H.; Sun, M.; Gan, H.; Song, G.; Sun, Z. Sequence stratigraphy and sedimentary facies of Lower Oligocene Yacheng Formation in deepwater area of Qiongdongnan Basin, Northern South China Sea: Implications for coal-bearing source rocks. J. Earth Sci. 2014, 25, 871-883. [CrossRef]

13. Catuneanu, O.; Abreu, V.; Bhattacharya, J.; Blum, M.; Dalrymple, R.; Eriksson, P.; Fielding, C.; Fisher, W.; Galloway, W.; Gibling, M.; et al. Towards the standardization of sequence stratigraphy. Earth Sci. Rev. 2009, 92, 1-33. [CrossRef]

14. Vail, P. Seismic stratigraphy and global changes of sea level. Bull. Am. Assoc. Petrol. Geol. Mem. 1977, $26,49-212$.

15. Ferreira, D.; Lupinacci, W.M.; Neves, I.D.A.; Zambrini, J.P.R.; Ferrari, A.L.; Gamboa, L.A.P.; Azul, M.O. Unsupervised seismic facies classification applied to a presalt carbonate reservoir, Santos Basin, offshore Brazil. AAPG Bull. 2019, 103, 997-1012. [CrossRef]

16. De Ruig, M.J.; Hubbard, S.M. Seismic facies and reservoir characteristics of a deep-marine channel belt in the Molasse foreland basin, Puchkirchen Formation, Austria. AAPG Bull. 2006, 90, 735-752. [CrossRef]

17. Du, H.-K.; Cao, J.-X.; Xue, Y.-J.; Wang, X.-J. Seismic facies analysis based on self-organizing map and empirical mode decomposition. J. Appl. Geophys. 2015, 112, 52-61. [CrossRef]

18. Zeng, $\mathrm{H}$. What is seismic sedimentology? A tutorial. Interpretation 2018, 6, SD1-SD12. [CrossRef]

19. Zhu, X.; Dong, Y.; Zeng, H.; Huang, H.; Liu, Q.; Qin, Y.; Ye, L. New development trend of sedimentary geology: Seismic sedimentology. J. Palaeogeogr. 2019, 21, 189-201. [CrossRef]

20. Liu, H.; Zhang, M.; Chi, X. Application of seismic sedimentology in a fluvial reservoir: A case study of the Guantao Formation in Dagang Oilfield, Bohai Bay Basin, China. Geol. J. 2021, 56, 5125-5139. [CrossRef]

21. Zeng, H.; Backus, M.M. Interpretive advantages of $90^{\circ}$-phase wavelets: Part 1-Modeling. Geophys. 2005, 70, C7-C15. [CrossRef] 
22. Zeng, H.; Zhu, X.; Zhu, R.; Zhang, Q. Guidelines for seismic sedimentologic study in non-marine postrift basins. Pet. Explor. Dev. 2012, 39, 295-304. [CrossRef]

23. Abbas, A.; Zhu, H.; Zeng, Z.; Zhou, X. Sedimentary facies analysis using sequence stratigraphy and seismic sedimentology in the Paleogene Pinghu Formation, Xihu Depression, East China Sea Shelf Basin. Mar. Pet. Geol. 2018, 93, 287-297. [CrossRef]

24. Luo, Y.; Huang, H.; Yang, Y.; Li, Q.; Zhang, S.; Zhang, J. Deepwater reservoir prediction using broadband seismic-driven impedance inversion and seismic sedimentology in the South China Sea. Interpretation 2018, 6, SO17-SO29. [CrossRef]

25. Zeng, H.; Zhao, W.; Xu, Z.; Fu, Q.; Hu, S.; Wang, Z.; Li, B. Carbonate seismic sedimentology: A case study of Cambrian Longwangmiao Formation, Gaoshiti-Moxi area, Sichuan Basin, China. Pet. Explor. Dev. 2018, 45, 830-839. [CrossRef]

26. Cao, L.; Chang, S.; Yao, Y. Application of seismic sedimentology in predicating sedimentary microfacies and coalbed methane gas content. J. Nat. Gas Sci. Eng. 2019, 69, 102944. [CrossRef]

27. Zeng, H.; Backus, M.M.; Barrow, K.T.; Tyler, N. Stratal slicing, Part I: Realistic 3-D seismic model. Geophysics 1998, 63, 502-513. [CrossRef]

28. Grana, D.; Della Rossa, E. Probabilistic petrophysical-properties estimation integrating statistical rock physics with seismic inversion. Geophysics 2010, 75, O21-O37. [CrossRef]

29. Verma, S.; Bhattacharya, S.; Lujan, B.; Agrawal, D.; Mallick, S. Delineation of early Jurassic aged sand dunes and paleo-wind direction in southwestern Wyoming using seismic attributes, inversion, and petrophysical modeling. J. Nat. Gas Sci. Eng. 2018, 60, 1-10. [CrossRef]

30. Zhang, S.; Huang, H.; Dong, Y.; Yang, X.; Wang, C.; Luo, Y. Direct estimation of the fluid properties and brittleness via elastic impedance inversion for predicting sweet spots and the fracturing area in the unconventional reservoir. J. Nat. Gas Sci. Eng. 2017, 45, 415-427. [CrossRef]

31. Meng, Z.-P.; Guo, Y.-S.; Wang, Y.; Pan, J.-N.; Lu, J. Predicting Models of Coal Thickness Based on Seismic Attributions and Their Applications. Chin. J. Geophys. 2006, 49, 450-457. [CrossRef]

32. Puryear, C.I.; Castagna, J.P. Layer-thickness determination and stratigraphic interpretation using spectral inversion: Theory and application. Geophysics 2008, 73, R37-R48. [CrossRef]

33. Ling, Y.; Gao, J.; Sun, D.; Lin, J. Spatially relative resolution based on geological concept and its application in seismic exploration. Geophys. Prospect. Pet. 2007, 46, 19.

34. Li, W.; Yue, D.; Wang, W.; Wang, W.; Wu, S.; Li, J.; Chen, D. Fusing multiple frequency-decomposed seismic attributes with machine learning for thickness prediction and sedimentary facies interpretation in fluvial reservoirs. J. Pet. Sci. Eng. 2019, 177, 1087-1102. [CrossRef]

35. Manzi, M.S.D.; Hein, K.; Durrheim, R.; King, N. Seismic attribute analysis to enhance detection of thin gold-bearing reefs: South Deep gold mine, Witwatersrand basin, South Africa. J. Appl. Geophys. 2013, 98, 212-228. [CrossRef]

36. Lyu, B.; Qi, J.; Li, F.; Hu, Y.; Zhao, T.; Verma, S.; Marfurt, K.J. Multispectral coherence: Which decomposition should we use? Interpretation 2020, 8, T115-T129. [CrossRef]

37. Zeng, H.; Marfurt, K.J. Recent progress in analysis of seismically thin beds. Interpretation 2015, 3, SS15-SS22. [CrossRef]

38. Hong, Z.; Li, K.-H.; Su, M.-J.; Hu, G.-M.; Yang, J.; Gao, G.; Hao, B. A DTW distance-based seismic waveform clustering method for layers of varying thickness. Appl. Geophys. 2020, 17, 171-181. [CrossRef]

39. Song, C.; Liu, Z.; Wang, Y.; Li, X.; Hu, G. Multi-waveform classification for seismic facies analysis. Comput. Geosci. 2017, 101, 1-9. [CrossRef]

40. Van Toorenenburg, K.A.; Donselaar, M.E.; Noordijk, N.; Weltje, G. On the origin of crevasse-splay amalgamation in the Huesca fluvial fan (Ebro Basin, Spain): Implications for connectivity in low net-to-gross fluvial deposits. Sediment. Geol. 2016, 343, 156-164. [CrossRef]

41. Li, C.; Ge, B. The sedimentary characteristic and sedimentary environments of the Shanxi Formation in the Yangquan coal district, Province Shanxi. J. Jiaozuo Min. Inst. 1985, 02, 33-51.

42. Omodeo-Salé, S.; Deschamps, R.; Michel, P.; Chauveau, B.; Suárez-Ruiz, I. The coal-bearing strata of the Lower Cretaceous Mannville Group (Western Canadian Sedimentary Basin, South Central Alberta), PART 2: Factors controlling the composition of organic matter accumulations. Int. J. Coal Geol. 2017, 179, 219-241. [CrossRef]

43. Liu, J.; Dai, S.; Hower, J.C.; Moore, T.A.; Moroeng, O.M.; Nechaev, V.P.; Petrenko, T.I.; French, D.; Graham, I.T.; Song, X. Stable isotopes of organic carbon, palynology, and petrography of a thick low-rank Miocene coal within the Mile Basin, Yunnan Province, China: Implications for palaeoclimate and sedimentary conditions. Org. Geochem. 2020, 149, 104103. [CrossRef]

44. Prinz, L.; Zieger, L.; Littke, R.; McCann, T.; Lokay, P.; Asmus, S. Syn- and post-depositional sand bodies in lignite-The role of coal analysis in their recognition. A study from the Frimmersdorf Seam, Garzweiler open-cast mine, western Germany. Int. J. Coal Geol. 2017, 179, 173-186. [CrossRef] 